GEOLOGICAL SURVEY CIRCULAR 755-B

\title{
Description of
Individual Data Items and \\ Description of
Individual Data Items and Codes in CRIB
}

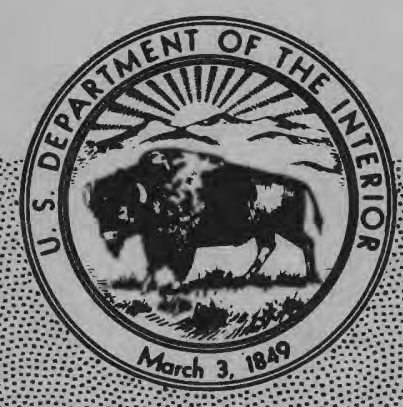




\section{Description of \\ Individual Data Items and Codes in CRIB}

By Eleanor K. Keefer and James A. Calkins

CRIB, the Mineral Resources Data Bank of the U.S. Geological Survey-

Guide for Public Users, 1977

GEOLOGICAL SURVEY CIRCULAR 755 - B 
United States Department of the Interior

CECIL D. ANDRUS, Secretary

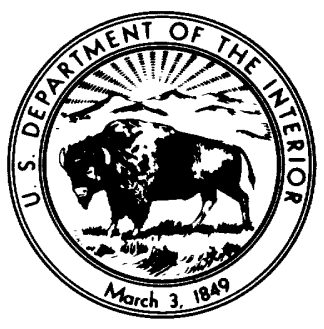

\section{Geological Survey}

W. A. Radlinski, Acting Director

Library of Congress catalog-card No. 78-600028 


\section{CONTENTS}

Abstract -.

Introduction

Individual data items

Index list of data items

Code lists
A. Record type
B. Status of exploration
C. CRIB country code list
D. State codes for United States and Prov- ince codes for Canada
E. Commodity codes
F. Deposit types (examples)
G. Accuracy

\begin{tabular}{|r|} 
Page \\
1 \\
2 \\
19 \\
22 \\
22 \\
22 \\
23 \\
\\
26 \\
26 \\
28 \\
28
\end{tabular}

Code lists-Continued

H. Measurement units

J. Drainage area codes of the United States _... 28

K. Physiographic provinces codes of the United States

Page 828 30

L. Nature of discovery

M. Type of work done _... 30

N. Form/shape of deposit (examples) - - $\quad 30$

O. Authorized age abbreviations _.....- 30

P. Land classification codes _._._._- 30

Glossary -

References cited . 32

\section{ILLUSTRATIONS}

Figure 1. Dummy record showing the standard output format of the CRIB mineral resources file

2. Size of deposit categories for the major metals 14

3. Diagram showing the classification of reserves and resources as used in the CRIB file

4. Map showing codes for drainage areas of the United States

5. Map showing codes for the physiographic provinces of the United States 


\title{
CRIB, THE MINERAL RESOURCES DATA BANK \\ OF THE U.S. GEOLOGICAL SURVEY- GUIDE FOR PUBLIC USERS, 1977
}

\section{DESCRIPTION OF INDIVIDUAL DATA ITEMS AND CODES IN CRIB}

\author{
By Eleanor K. Keefer and James A. Calkins
}

\begin{abstract}
The U.S. Geological Survey's Computerized Resources Information Bank (CRIB) is being made available for public use through the computer facilities of the University of Oklahoma and the General Electric Company, USA. The use of General Electric's worldwide information-services network provides access to the CRIB file to a worldwide clientele. This manual, which consists of two chapters, is intended as a guide to users who wish to interrogate the file. Chapter A contains a description of the CRIB file, information on the use of the GIPSY retrieval system, and a description of the General Electric Mark III Service. Chapter $B$ contains a description of the individual data items in the CRIB record as well as code lists.

CRIB consists of a set of variable-length records on the metallic and nonmetallic mineral resources of the United States and other countries. At present, 31,645 records in the master file are being made available. The record contains information on mineral deposits and mineral commodities. Some topics covered are: deposit name, location, commodity information, description of deposit, geology, production, reserves, potential resources, and references.
\end{abstract}

The data are processed by the GIPSY program, which maintains the data file and builds, updates, searches, and prints the records using simple yet versatile command statements. Searching and selecting records is accomplished by specifying the presence, absence, or content of any element of information in the record; these specifications can be logically linked to prepare sophisticated search strategies. Output is available in the form of the complete record, a listing of selected parts of the record, or fixed-field tabulations.

The General Electric Mark III Service is a computerized information services network operating internationally by land lines, satellites, and undersea cables. The service is available by local telephone to 500 cities in North America, Western Europe, Australia, Southeast Asia, Japan, and Saudi Arabia. An interface called the "foreground driver" is used to link the GIPSY program to the General Electric system.

\section{INTRODUCTION}

The U.S. Geological Survey's (USGS) Computerized Resources Information Bank (CRIB) is being made available for public use through the computer facilities of the University of Oklahoma and the General Electric Company MARK III Service. ${ }^{1}$ This chapter contains a description of the individual data or information items ${ }^{2}$ in the CRIB record, an index list of the data items, and a set of code lists. The information in Chapter $B$ will be of assistance in understanding the file content and in formulating useful retrievals. Although approximately 400 data items are available, one record is unlikely ever to contain information on all these data items.

A data item is the smallest unit of information to which reference is made in a record. A data item consists of one or more of the following four main components: (1) Label, (2) item (label) description, (3) field (associated with the label), and (4) data (contained in the field).

The minimum requirement for defining a data item is a label. The label as used in the GIPSY program is a unique alphanumeric identifier of 1-7 characters. All data items in the CRIB record are defined in terms of a label, and the collection of all labels in the record constitutes the data dictionary or search dictionary. The label can be thought of loosely as the name of a field of a given data item, and

\footnotetext{
'MARK III is a registered service mark of General Electric Company, USA.

" "Data" and "information" are synonyms in most of their senses and are used interchangeably in this manual. In the strict sense, the term "data" constitutes facts and figures (as the number "15"), and when meaning is assigned to this number, it becomes "15"), and when meaning is assigned to this number, it becomes (data) is meaning; therefore, "data" implies information, and so the two words are synonyms.
} 
it serves to identfy each field or data item to the user and to the GIPSY program. For example, the label A10 defines the field containing the DEPOSIT NAME. The label is the basis for identifying fields to be searched during a retrieval.

The item description is an optional descriptor associated with a given label. It consists of 1-59 characters and serves to describe the data item in readable English on the printout or to perform the function of a header line. For example, the label A10 has the item description DEPOSIT NAME associated wtih it, and the label A1 generates the header line NAME AND LOCATION.

The field is the computer storage space made available to store data. All fields are taken as variable-length fields by the GIPSY program. However, these variable-length fields can be rigidly formatted by controlling the length and nature of the data entered into the fields; thus, many fields in the CRIB record are equivalent to fixed-length fields.

The data is the alphanumeric entry placed in the field. It may consist of text, a number, a code, or keywords.

\section{INDIVIDUAL DATA ITEMS}

This section contains a detailed description of each data item. The data items are arranged label by label in the order in which they are printed in the standard output record (see dummy record, fig. 1). The material includes the label, item description, format (if any) of data contained in the field, what the data mean, how the field is used, and other information. Following the descriptions of many labels is a code letter, or letters, indicating one or more key characteristics of that label, of the item description, of the field, or of the data contained in the field. The meaning of these codes is as follows:

L _._. Item (label) description only appears in output record. No entry is associated with the labels and the item description itself constitutes the data. Data items of this type are treated as literals (see Chapter A, p. A8) when used in the COPY, SORT, or COUNT commands.

$\mathrm{N}$ _.__N Numeric field or alphanumeric field treated as a numeric field.
F _._. Formatted field.

PF _._. Partially formatted field or field containing key words or codes of varying lengths.

D _._. Discontinued label. Entries may appear on early records, but the label is no longer in use for current input.

NS _. Label not on standard input form $10(9-76)$.

C .... A coded field. Entries are coded from code list indicated.

\section{RECORD IDENTIFICATION}

B10 Record number.-The record number is a unique identifying code assigned to each record in the file; it is alphanumeric and usually contains seven characters. (F).

\section{Record type.-}

A.-Form A used as source document. (NS, L, D).

B.-Form B used as source document. (NS, L, D) .

D.-Special-purpose form used as source document. (NS, L, D).

U.-Record that has been updated. Updating can include significant or material additions, deletions, or other changes to the original data in one or more fields of the record. It does not include simple spelling or other minor typographical corrections. (L).

S.-Short form used as source document. (NS, L, D).

L.-Long form used as source document.

(NS, L, D).

USGS Country/organization.-An international code indicating the country where the file resides and the organization maintaining the file-in this example, the United States Geological Survey. (L).

B30 Source.-Used to indicate a primary source file (computerized or not) when the File Link ID (B50) is used for a secondary rather than a primary source. (NS).

B50 File Link ID.-An entry in this field indicates that further information on this locality is stored in some other file, either computerized or not. Examples of keyword entries in this field are RASS (Rock Analysis File), USBM (Bureau of Mines data), GEOPHY (Geophysical files), BLM (Bureau 

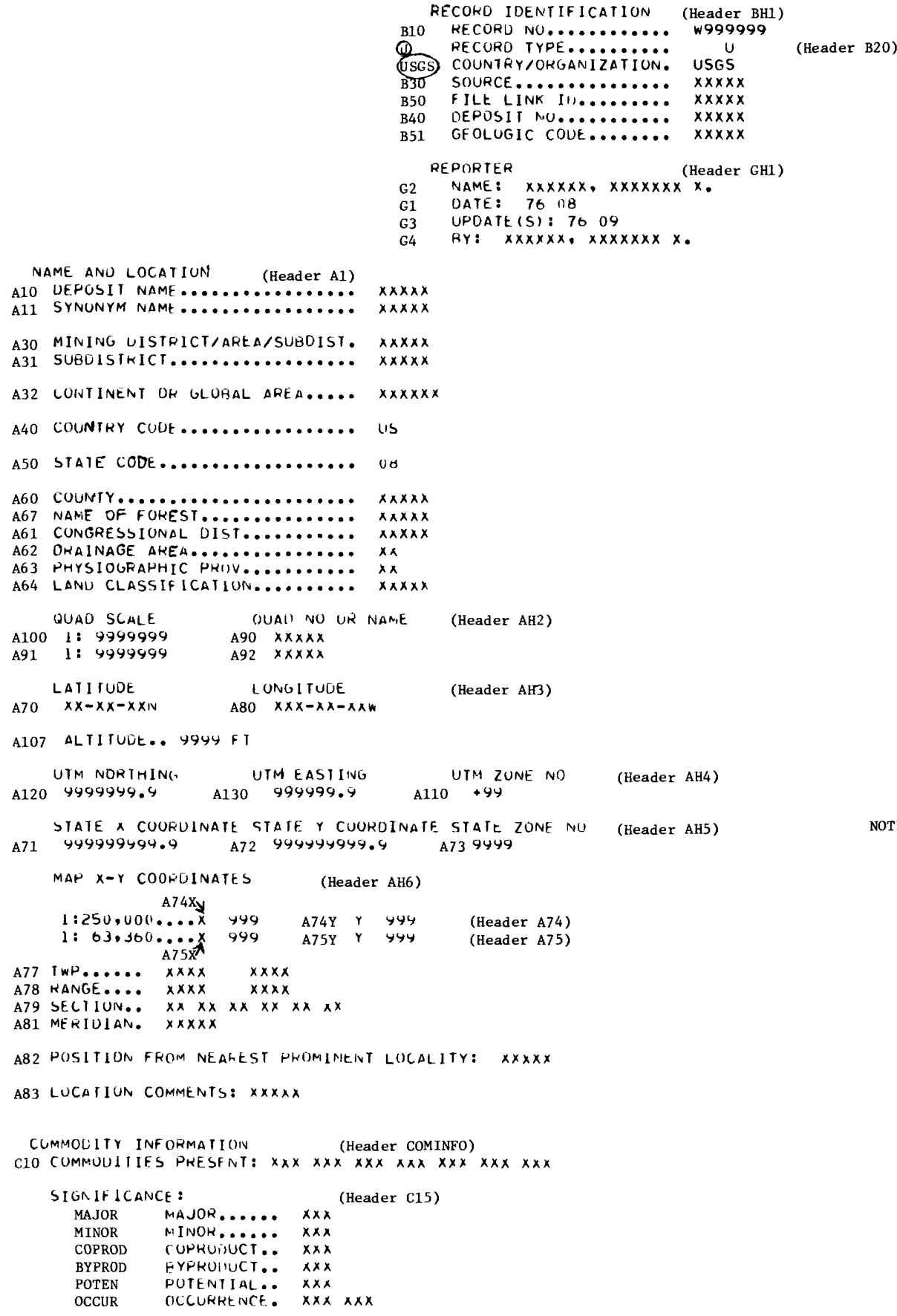

C20 CUMMUUIIY SFECIALIST INFURNATIUN: $x \times x$

C21 SPELCIAL FIELD $1 \times x \times x \times$

C22 SHECLAL FIELD $2 \times x \times x \times$

C23 SPECIAL FItLU I $x \times x \times x$

FIGURE 1.-Dummy record showing the standard output format of the CRIB mineral resources file. 


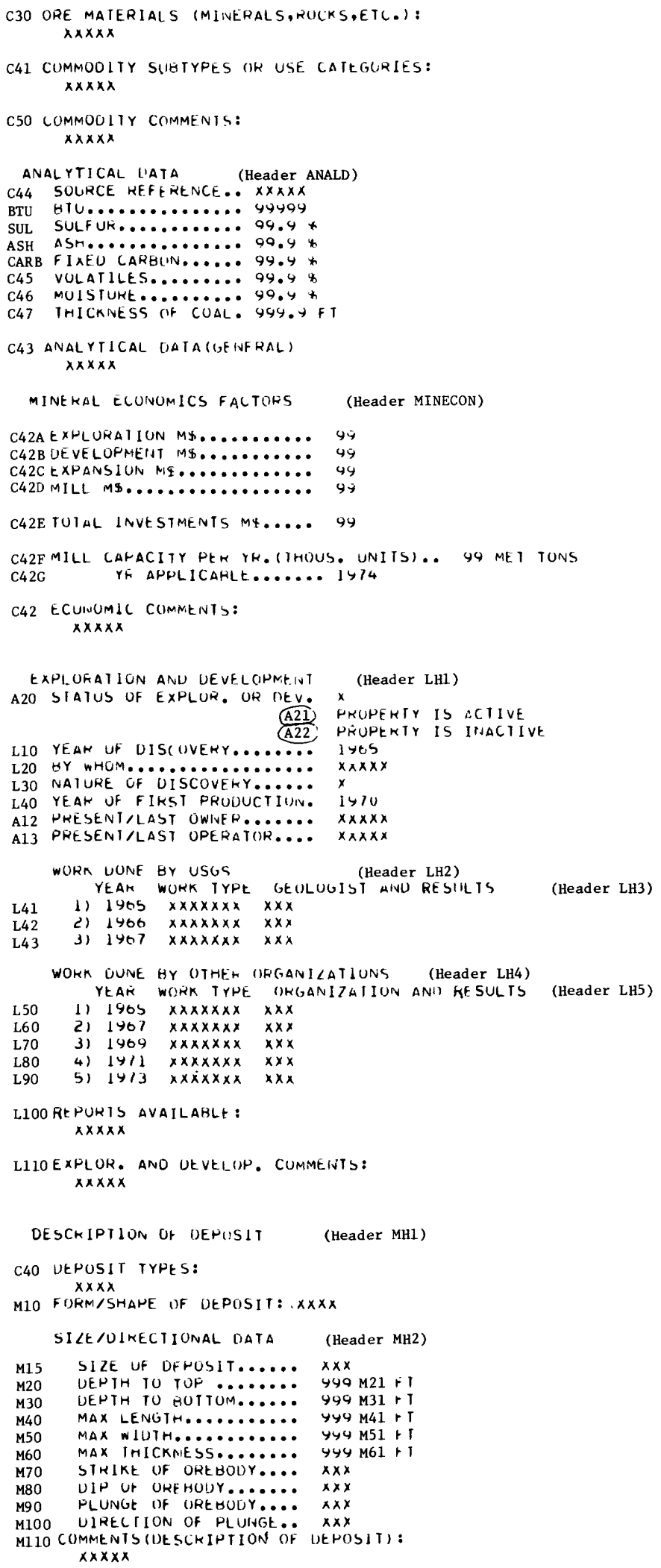

FIGURE 1.-Dummy record showing the standard output format of the CRIB mineral resources file-Continued. 
M140 SURFACE ANU UNDERGRUUNO

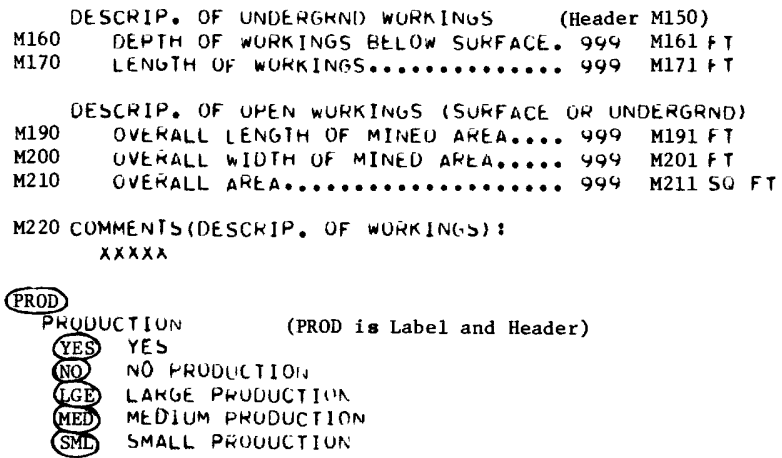

DH. ANNUAL PRUDUCIIUN (URE ANU LOMMUOITIES)

(DH is Label and Header)

\begin{tabular}{|c|c|c|c|c|c|c|c|c|}
\hline & \multicolumn{2}{|c|}{ I IEM } & $A C C$ & AMUUNT & TMUUS.UNI IS & $Y+\Delta H$ & GHALE OK IISE. & (Header \\
\hline D1 & 1 & $x \times x \times$ & $x \times x$ & 94494990 & $x \times x \times x \times x \times$ & 1470 & $x \times x \times x$ & \\
\hline D2 & $e$ & $x \times x x$ & $x \times x$ & 94994994 & $x \times x \times x \times x \times$ & 1470 & $x \times x \times x$ & \\
\hline D3 & 3 & $x \times x \times$ & $x \times x$ & ૧૭9૫9૧૫૫ & $x \times x \times x \times x \times$ & 1970 & $x \times x x x$ & \\
\hline D4 & 4 & $x \times x x$ & $x \times x$ & 99494994 & $x \times x \times \times \times \times x$ & 1470 & $x \times x \times x$ & \\
\hline D5 & $b$ & $x \times x \times$ & $x \times x$ & ૬४४४У৭४૬ & $x \times x \times x \times x \times$ & 1970 & $x \times x \times x$ & \\
\hline D6 & 0 & $x \times x \times$ & $x \times x$ & ৭४४४४৭४४ & $x \times x \times x \times x \times$ & $1 \rightarrow / 0$ & $x \times x \times x$ & \\
\hline D7 & 7 & $x \times x \times$ & $x \times x$ & $\underbrace{94944990}$ & xxxxxx. & $\underbrace{1470}$ & $\underbrace{x \times x \times x}$ & \\
\hline & & & & $D 1 A-D 7 A$ & D1B-D7B & $C-D 7 C$ & D1D-D7D & \\
\hline
\end{tabular}

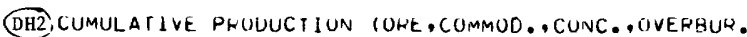

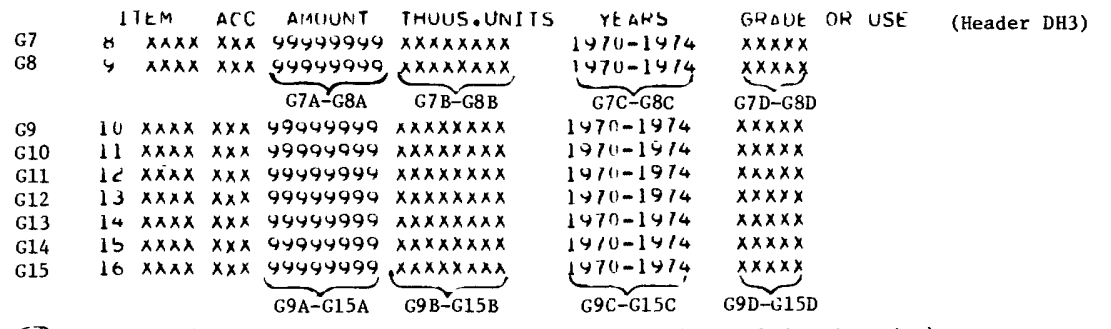

(DH4) OVERURUEN AND CONCENTRATES (ANNUAL)

(DH4 is Label and Header)

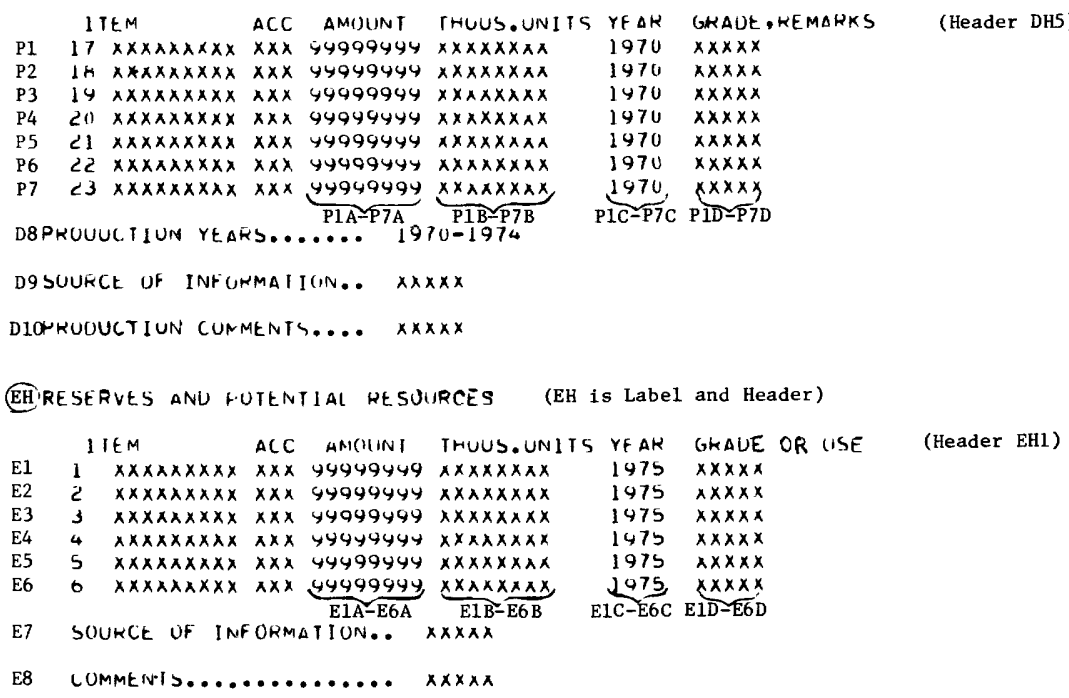

FIGURE 1.-Dummy record showing the standard output format of the CRIB mineral resources file-Continued. 


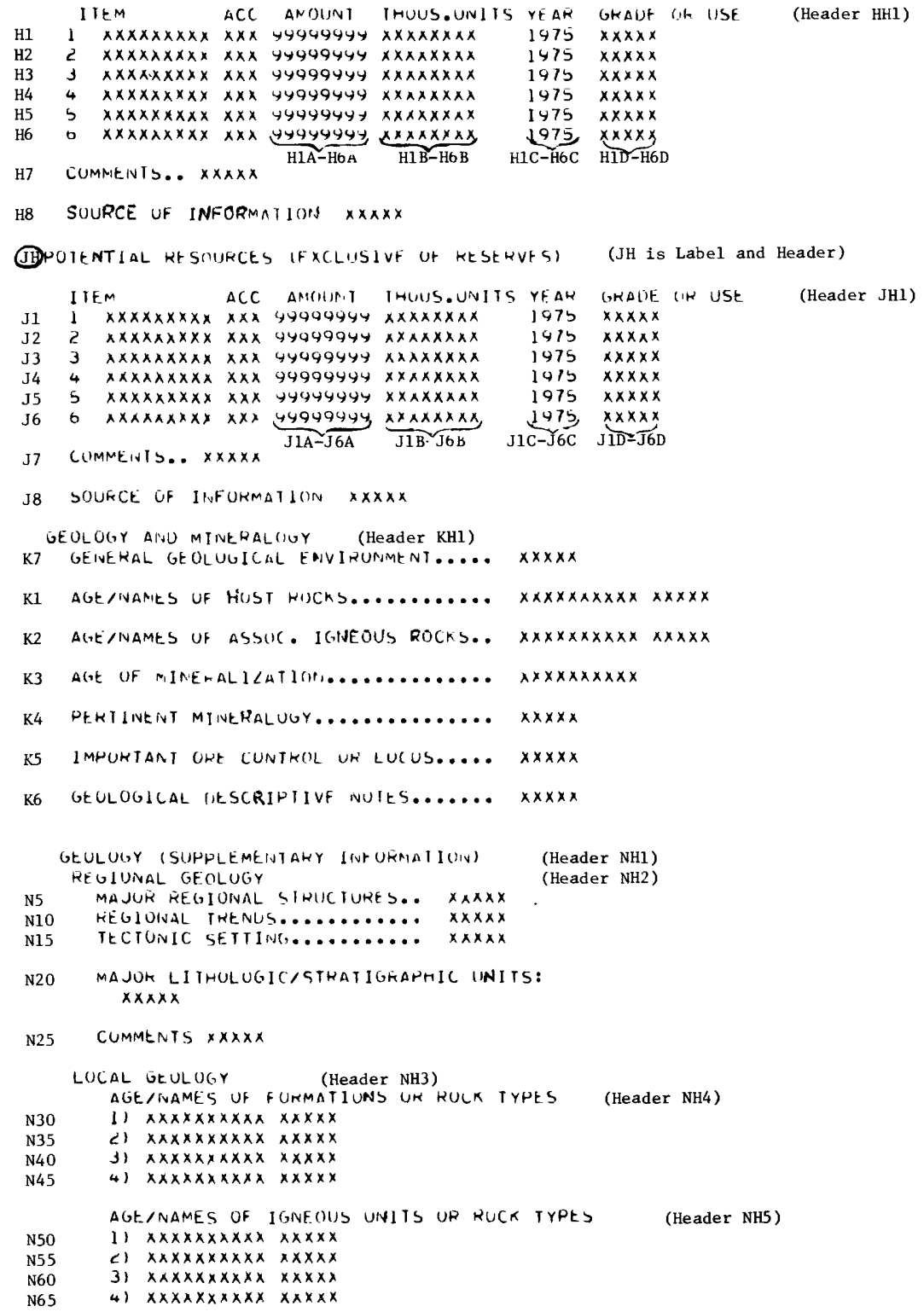

Figure 1.-Dummy record showing the standard output format of the CRIB mineral resources file-Continued. 
N75 SIGINIFICANT ALTERAIIUN: $x \times \times \times x$

N80 GEOLUGICAL HKUCFSSFS UH LONCENIKATION ON ENKICWMENT: $x \times x \times x$

N85 CUMMENTS (GEOLOGY ANR MIINERALUGY): $\times \times \times \times \times$

GEN GENERAL CUMMER IS

$x \times x \times x$

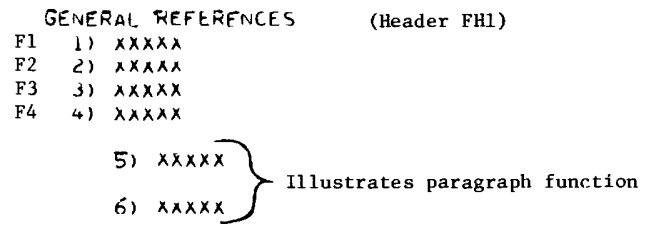

FIGURE 1.-Dummy record showing the standard output format of the CRIB mineral resources file-Continue. 
of Land Management data), CONSV (USGS Conservation Division data), TVA (Tennessee Valley Authority), FS (U.S. Forest Service), and GUILD (metallogenic map file). (PF).

B40 Deposit number.-The deposit number is used optionally by reporters for file numbers; for a series of localities of a given commodity ; for a sequence of mineral localities; for field numbers; or for any other individual numbering system.

B51 Geologic code.-A coding system used in a special file on metallogenic map data. (NS).

\section{REPORTER}

G2 Name.-Name of the reporter who filled out the original source document (or the geologist under whose supervision this was done). (PF).

Format:

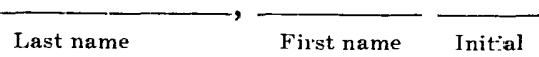

G1 Date.-Date the original source document was filled out. $(\mathrm{F}, \mathrm{N})$.

Format:

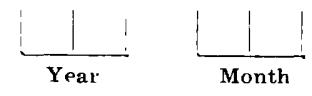

G3 Update(s).-Date the record was updated. $(\mathrm{F}, \mathrm{N})$.

Format:

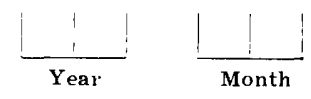

G4 By.-The person who updated the record. (PF).

Format:

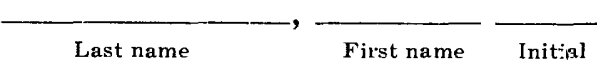

NAME AND LOCATION

A10 Deposit name.-The most commonly used name of the mineral deposit, district, mine, prospect, claim, or occurrence. The deposit name also is used to identify summary records (for example, Zinc, Country Summary -Peru).

A11 Synonym name(s).--Other names by which the deposit is known.

A30 Mining district/area subdistrict.- Name of the mining district, area, subdistrict, or other large mineral-area name or regional geographic name.
A31 Subdistrict.-For optional use when district is divided into subdistricts. (NS).

A32 Continent or global area.-Intended to designate entire continents or large global areas (such as the Southwest Pacific). (NS).

A40 Country code.-Country in which the deposit is found. Each country is coded by two alphabetic characters-see CRIB Country Code List (List C, p. B23-B25). (C, F).

A50 State code.-State, Province, or other second-order political subdivision below the country level. States in the United States and Provinces in Canada are coded by two numeric characters-see State Codes for U.S. and Province Codes for Canada (List D, p. B26). In other countries, the State or Province names are written out. (C, F).

A60 County.-Names (s) of the county (ies) or other third-order political subdivision(s). Census divisions may be used in Alaska.

A67 Name of forest.-Used mainly in records generated by the U.S. Forest Service. (NS).

A61 Congressional District.-Congressional District in which the deposit is located. (NS).

A62 Drainage area.-The drainage area in which the deposit is located. See Drainage Area Codes of the U.S. (List J, p. B28 and fig. 4). The numeric code for a drainage area is entered in the first two spaces in the field. The rest of the entry is used to describe the drainage area further (For example, the code 02 indicates the Middle Atlantic region, and "Upper Hudson River" indicates the specific drainage area.) or to enter information about the drainage area of a non-U.S. mineral deposit. (PF, C).

A63 Physiographic province.-The physiographic province in which the deposit is located. See Physiographic Provinces Codes of the U.S. (List K, p. B30 and fig. 5). The numeric code for a U.S. physiographic province is entered in the first two spaces in the field. The rest of the entry is used to describe the physiographic province further (for example, Southern Catskills) or to describe the province of a non-U.S. deposit. (PF, C).

A64 Land classification.-A two-digit coded field classifying the land in terms of privateland ownership and various types of public lands-see Land Classification Codes (List 
$P$, p. B30). This is a recently added field and as yet contains little data. (C, F).

A100 Quadrangle scale.-Under quadrangle scale is entered the denominator of the fractional scale of the map of the quadrangle where the deposit is located (For example, if the scale is $1: 24,000$, then the entry is 24000). (N, F).

Format:

(right

justified)

A90 Quadrangle number or name.-The number or name of the quadrangle in which the mineral deposit is located. Quadrangle index maps and map information are available from the National Cartographic Information Center, U.S. Geological Survey, 507 National Center, Reston, Va. 22092.

A91 Second quadrangle scale.-Available for use if a second quadrangle (usually of different scale) is involved. Format same as A100 above. (NS, F, N).

A92 Second quadrangle number or name.Similar to A90 above. Used when a second quadrangle is reported. (NS).

Location methods.-Four possible location methods available are: geodetic coordinates, Universal Transverse Mercator coordinates, State Grid coordinates, and the public-land survey (township-range-section) system. In addition, an $\mathrm{X}-\mathrm{Y}$ cartesian coordinate system is available for special-purpose use. Usuually just one of these methods is used by a reporter, but in some records, two methods (such as, latitude and longitude and also township, range, and section) may be used.

Geodetic coordinates.-For the two fields-A70 Latitude and A80 Longitude-please note that when an exact location is not available, reporters have used an arbitrary center point or the coordinates of a principal mine or quarry. Even though a single-point location may not be a realistic "center," nevertheless, an arbitrary location is important so that the area in question can be retrieved on the basis of latitude and longitude.

For an example of a retrieval based upon latitude and longitude see chapter A, fig. 7, of this report.
Aro Latitude (F).

Format:

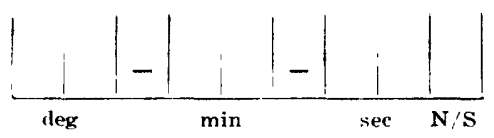

A80 Longitude (F).

Format:

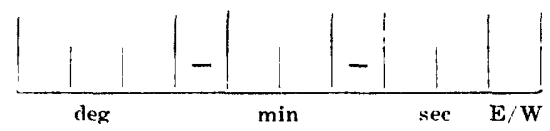

$10 \%$ Altitude (N, PF).

Usual format: $\quad|\mathbf{9}| \mathbf{9}|\mathbf{9}| \mathbf{9} \quad \underline{\mathrm{F} \mid \mathrm{T}}$

This is the surface elevation of the item being described (mine, prospect, or district). For a large area, the altitude of a point, or an average altitude is reported. The usual format is digits followed by a space, then FT or M (feet or meters).

UTM coordinates

A120 UTM northing $(\mathrm{F}, \mathrm{N})$.

$$
\begin{array}{l|l|l|l|l|l|l|l|l|}
\mathbf{9} & \mathbf{9} & \mathbf{9} & \mathbf{9} & \mathbf{9} & \mathbf{9} & \mathbf{9} & \cdot & \mathbf{9} \\
\hline
\end{array}
$$

A130 UTM easting $(\mathrm{F}, \mathrm{N})$.

$$
\mathbf{9}|\mathbf{9}| \mathbf{9}|\mathbf{9}| \mathbf{9}|\mathbf{9}| \cdot|\mathbf{9}|
$$

A110 UTM zone number $(\mathrm{F}, \mathrm{N})$.

$$
\pm \mathbf{\pm} 9
$$

The Universal Transverse Mercator grid is shown on all USGS quadrangle maps printed since 1956. To define a point in the UTM system, a northing, easting, and zone number are required. The world is divided into 60 meridional zones numbered from 1 to 60 ; each zone covers a strip $6^{\circ}$ wide in longitude.

Zones north of the equator are positive $(+)$; zones south of the equator are negative $(-)$. The zone number is indicated in the lower left corner of $71 / \mathrm{g}-$ minute topographic sheets. Within each zone coordinates are measured in meters north of the equator and east of the west boundary of the zone. Grid lines drawn on the base map, together with a metric coordinate reader, make it possible to plot a point in the UTM system. 
The following is an example of a point in the Northern Hemisphere:

UTM northing

$$
|3| 5|9| 8|8| 8|7| \text {. }
$$

UTM easting

\begin{tabular}{|l|l|l|l|l|l|} 
& $\mathbf{9}$ & 0 & 1 & $\mathbf{2}$ & 3 \\
\hline
\end{tabular}

UTM zone no.

$$
1+1 \mid 7
$$

\section{State Coordinates}

Ar1 State $X$ coordinate $(\mathrm{F}, \mathrm{N})$.

\begin{tabular}{l|l|l|l|l|l|l|l|l|l|l|}
$\mathbf{9}$ & $\mathbf{9}$ & $\mathbf{9}$ & $\mathbf{9}$ & $\mathbf{9}$ & $\mathbf{9}$ & $\mathbf{9}$ & $\mathbf{9}$ & $\mathbf{9}$ &. & $\mathbf{9}$ \\
\hline
\end{tabular}

Ar2 State $Y$ coordinate $(\mathrm{F}, \mathrm{N})$.

$$
\begin{array}{|l|l|l|l|l|l|l|l|l|l|l}
9 & \mathbf{9} & \mathbf{9} & \mathbf{9} & \mathbf{9} & \mathbf{9} & \mathbf{9} & \mathbf{9} & \mathbf{9} & \text {. } & \mathbf{9} \\
\hline
\end{array}
$$

Ars State zone number $(\mathrm{F}, \mathrm{N})$.

$$
\begin{array}{l|l|l|l}
\mathbf{9} & \mathbf{9} & \mathbf{9} & \mathbf{9}
\end{array}
$$

Each state has its own coordinate system, and these can be used as location coordinates. State coordinate ticks are printed on the edges of most topographic maps.

Detailed descriptions of the State coordinate systems can be obtained from the appropriate State agencies. A listing of the the four-digit zone numbers for each State can be found in "Program Description, D0154” (Buehrer, 1969, unpub. data), available from the U.S. Geological Survey Computer Center, 801 National Center, Reston, Va. 22092.

Map X-Y coordinates

A74X X (map coordinate for 1:250,000scale map) (NS, N).

A74Y Y (map coordinate for 1:250,000scale map) (NS, N).

A75X X (map coordinate for 1:63,360scale map) (NS, N).

A75Y Y (map coordinate for $1: 63,360$ scale map) (NS, N).

An example of an X-Y coordinate system is that used in many records on Alaska, in which each mineral location is referenced in $\mathrm{X}-\mathrm{Y}$ on $1: 250,000$-sc̀ale maps and also on 1:63,360-scale maps when available. This location system may in the future come into wider use, especially in locating drillholes.

Arr Tounship(s). - Space is provided for two townships on the standard form. Three spaces are allotted for digits, followed by a space for $N$ (north) or $S$ (south) in each. (F).

Format:

$$
0,3|8| \mathrm{N}|, \quad| \quad|0| 3|9| \mathrm{N} \mid
$$

Ars Range(s).-Dpace is provided for two ranges on the standard form. Three spaces are allotted for digits, followed by a space for $\mathrm{E}$ (east) or $\mathrm{W}$ (west) in each. (F).

Format:

$$
\underline{0|0| 9|\mathrm{E}|} \quad|\quad| 0|1| 0|\mathrm{E}|
$$

A:9 Section(s).-Dpace is provided for six sections (two digits each). If only one TwpRge is entered, all six sections may refer to that single township. If, however, two Twp-Rge locations are given, the first three sections may refer to the first TwpRge and the 4 th, 5 th, and 6 th sections may refer to the second Twp-Rge.

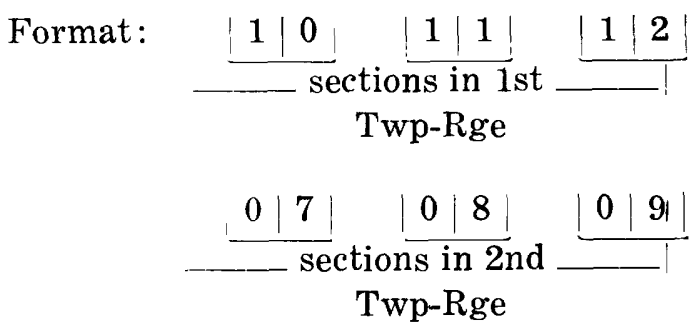

A81 Meridian.-The name of the meridian that governs the set of townships and ranges. In some records, this has been abbreviated when entered.

A82 Position from nearest prominent locality. - This can include the direction and distance of the location from some nearby town or prominent geographic feature or other pertinent information.

On some records in the CRIB file, this field is used to indicate the position within the section (that is, the quarter section). 
A83 Location comments.-Contains any comments concerning the location of the deposit.

\section{COMMODITY INFORMATION}

C10 Commodities present.-A fixed field containing seven subfields of four spaces each. This provides for listing of as many as seven commodities in a given mineral deposit. The subfields are occupied as in the examples given below. Note that entries are left justified in each subfield.

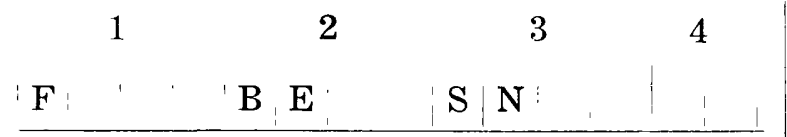

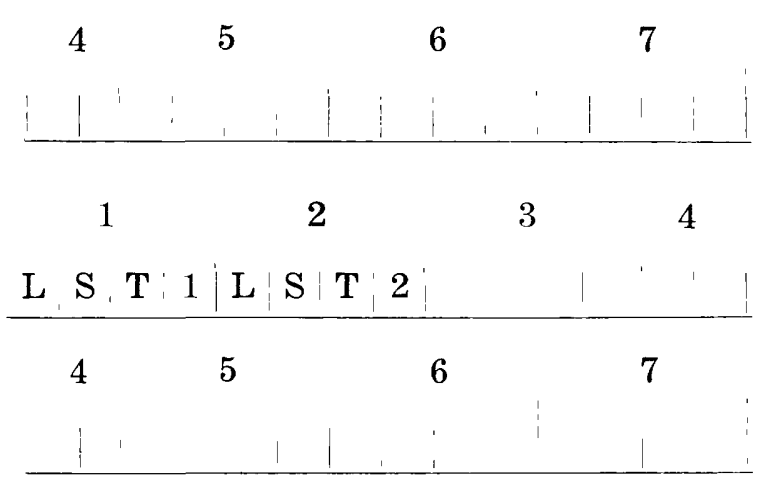

The codes for commodities are in LIST E ( $p$. B26-B28). Element codes are the standard chemical symbols of one or two letters. Other commodities are coded in three letters or three letters and a number. (F, C).

Significance.-This section classifies the commodities shown in $\mathrm{C} 10$ into major or minor products, coproducts, byproducts, potential products, and occurrences. Codes used in these six fields and method of entry are the same as in C10. In many records, the reporters have entered commodities in the C10 field without breaking them down into their significance here.

MAJOR Major product (F, C).

MINOR Minor product $(\mathrm{F}, \mathrm{C})$.

Four subfields of four spaces each are allowed for each of the above two fields.

COPROD Coproduct $(\mathrm{F}, \mathrm{C})$.

BYPROD Byproduct $(\mathrm{F}, \mathrm{C})$.

POTEN Potential (F, C).

OCCUR Occurrence $(\mathrm{F}, \mathrm{C})$.

Three subfields of four spaces each are allowed for each of the above four fields.
C20 Commodity specialist information.-Commodity codes from List E (p. B26-B28) will be entered here (in the same format as in $\mathrm{C} 10$ ) when the following conditions apply : (1) The reporter is a commodity specialist and is supplying information on his own commodity, or (2) information is obtained from sources that were originally compiled by a commodity specialist. Four subfields of four spaces each are allowed for C20.

C21 Special field 1 (NS).

C22 Special field 2 (NS).

C23 Special field 3 (NS).

The above three fields are used by commodity specialists for special information not entered into other fields.

C30 Ore materials (minerals, rocks, and so on). - This field is for the names of the most important ore minerals, rocks, or other ore materials.

C41 Commodity subtypes or use categories.This field provides for the subdivision of commodities into specialized subtypes, if needed, or into categories based upon end use.

Example: Bauxite coded AL1 in C10, could be further classified as:

C41 < BAUXITE, REFRACTORY

GRADE >

C50 Commodity comments.-Comments pertaining to the commodity information section are entered here.

\section{ANALYTICIAL DATA}

This section includes certain fields relating to coal, plus a general field for other types of analytical data.

C44 Source reference.-Refers to the source reference for the analytical data.

$B T U$ BTU.-British Thermal Units ( N, F).

Format :

SUL Sulfu.-Sulfur content in weight percent $(\mathrm{N}, \mathrm{F})$.

Format:

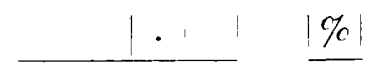

$A S H$ Ash.-Ash content in weight percent (N, F).

Format:

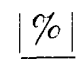


$C A R B$ Fixed carbon.-Fixed carbon in weight percent $(\mathrm{N}, \mathrm{F})$.

Format :

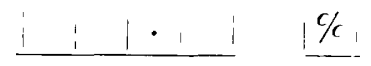

C45 Volatile material.-Volatile material in weight percent $(\mathrm{N}, \mathrm{F})$.

Format:

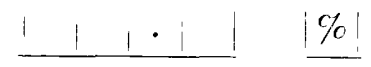

C46 Moisture.-Moisture content in weight percent $(\mathrm{N}, \mathrm{F})$.

Format:

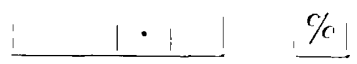

C4\% Thickness of coal.-Thickness of coal in feet or meters $(\mathrm{N}, \mathrm{F})$.

Format: or $\mathbf{M}$ )

C4.3 Analytical data (General).-This field is available for other types of analytical data.

\section{MINERAL ECONOMICS FACTORS}

This section contains a limited number of fields relating to the economics of a mining operation. These include (in the millions of dollars): the costs for exploration, development, and expansion of the mining operation; the cost of the mill; the total investment; and the mill capacity (in tons or other units). A field also is available for general economic comments. These fields are listed below :

C42A Exploration $M \$(\mathrm{~N})$.

$C 42 B$ Development $M \$(\mathrm{~N})$.

C42C Expansion $M \$(\mathrm{~N})$.

$C 42 D$ Mill $M \$(\mathrm{~N})$.

C42E Total investments $M \$(\mathrm{~N})$.

C42F Mill capacity per year.-In thousands of metric tons (or other units) per year.

( $\mathrm{N}, \mathrm{PF})$.

C42G Year applicable.

C42 Economic comments. - This field is used for any comments relating to economic factors that might govern or affect the exploration of the deposit or commodity. These could include such items as distance to market, railroad, or road; high altitude; labor or price situation; favorable or unfavorable mining conditions; or unusual milling problems.

\section{EXPLORATION AND DEVELOPMENT}

A:0 Status of exploration or development.This field shows the degree of development of the deposit into four categories in terms of the surface and underground information available. It will be coded by one of the number codes from Status of Exploration or Development (List B, p. B22). (C).

$A \gtrsim 1$ Property is active.-This entry is intended to indicate whether there was any activity at the time the record was reported. It is applicable mainly to specific tangible localities (such as prospects, mines, or districts). Activity includes production or any present-day exploration or development work. (L).

A.2 Property is inactive.-Indicates that the property was inactive at the time the record was reported. (L).

L10 Year of discovery. - The year or approximate year of discovery is entered here. In some records, generalized entries such as PREHISTORIC, PRESPANISH, OR REVOLUTIONARY WAR may have been used here

L:O By uhom.-Name of company, organization, or person most closely involved in the discovery.

L30 Nature of discovery.-Codes of one letter each are used here to describe the nature of discovery. (See Nature of Discovery, List L, p. B30). If the letter $F$ is used indicating "other," this may be clarified under the comments field L110.

L4) Year of first production.-This field indicates the year or approximate year of first production. The same kind of entries are used here as in L10 above.

A12 Present or last owner.-The name of the person or organization that owns or recently has owned the mineral rights to the deposit.

A13 Present or last operator. - The name of the person or mining company that is actually working the deposit or that most recently worked it, if it is now inactive. If the operator is the same as the owner, this name should appear in both A12 and A13.

\section{W'ORK DONE BY USGS}

Three lines, each constituting a single field, are available in this table allowing for the accommodation of the following three subfields: 
Year.-The year the work was done or started.

Format:

$$
\begin{array}{|l|l|l|l|}
1 & 9 & 7 & 5 \\
\hline
\end{array}
$$

Type of work.-Codes are used here from Type of Work Done (List M, p. B30). If OTHER is entered, it may be clarified in comments field L110. Seven spaces are allowed here.

Format: $\quad \mathrm{X}|\mathrm{X}| \mathrm{X}|\mathrm{X}| \mathrm{X}|\mathrm{X}| \mathrm{X}$

Geologist and results.-Name of geologist within the USGS and the results of his (her) work.

L41 (1st line of table) (C, PF, N).

L42 (2nd line of table) (C, PF, N).

L4.3 (3rd line of table) (C, PF, N).

\section{WORK DONE BY OTHER ORGANIZATIONS}

Five lines, each constituting a single field, are available in this table allowing for the accommodation of the following subfields:

Year.-The year the work was done or started.

Format:

$$
\begin{array}{|l|l|l|l|}
1 & 9 & 7 & 5 \\
\hline
\end{array}
$$

Type of work.-Codes are used here from Type of Work Done (List M, p. B30). If OTHER is entered here, it may be clarified in the field L110.

Format:

$$
\mathrm{X}|\mathrm{X}| \mathrm{X}|\mathrm{X}| \mathrm{X}|\mathrm{X}| \mathrm{X} \mid
$$

Organization and results.-Name of the organization that did the work and the results.

L50 (1st line of table) (PF, C, N).

L60 (2nd line of table) (PF, C, N).

L\%0 (3rd line of table) (PF, C, N).

L80 (4th line of table) (PF, NS, C, N).

L90 (5th line of table) (PF, NS, C, N).

L100 Reports available.-This field is for citing available reports, either published or unpublished, that deal with the exploration and development of the deposit.

L110 Exploration and development comments. -Comments on exploration and development, if necessary to clarify the above entries in this section.

\section{DESCRIPTION OF DEPOSIT}

C40 Deposit types.-Examples of entries in this field are given in Deposit Types (List F, p. B28). This list is not exhaustive, and other deposit types may have been used. (PF).
M10 Form/shape of deposit.-Entries from Form/Shape of Deposit (List N, p. B30) are commonly found in this field. This list is not exhaustive, and other descriptive terms may be used. (PF, C).

\section{Size directional data}

M15 Size of deposit.-The general size of the deposit will commonly be indicated by one of the key words: LARGE, MEDIUM, or SMALL. In some records the actual size is entered (in acres, sq km). Size, following the scheme devised for the metallogenic map of North America (Guild, 1968), relates to the amount of metal or mineral contained in the deposit, district, or area being described. This scheme, which shows the most common metals, is shown in figure 2. The key words represent different value ranges for the different commodities. For example, an iron mine containing about 150 million tons of iron would probably be considered a LARGE mine, whereas a LARGE gold mine would contain only about 500 tons of gold. (PF).

Abbreviations for units.-In the following pages, certain fields are units fields associated with numeric entries. The abbreviations of these units are shown in Measurement Units (List H, p. B28). In the numeric fields, the figures given may represent only rough averages. These fields, although not formally defined as to field length, are nevertheless formatted fields because the data automatically start in position one.

M20 Depth to top (numeric field.-Distance from the surface to the highest point of the deposit. $(\mathrm{N}, \mathrm{F})$.

M21 (units associated with M20) (C, PF).

M30 Depth to bottom (numeric field).-Distance from the surface to the lowest point of the deposit. (N, F).

M31 (units associated with M30) (C, PF).

M40 Maximum length (numeric field).Overall length of the deposit, measured in the horizontal plane. $(\mathrm{N}, \mathrm{F})$.

M41 (units associated with M40) (C, PF).

M50 Maximum width (numeric field).Overall width of the deposit, measured in the horizontal plane. Applies mainly to steeply dipping deposits, such as veins. $(\mathrm{N}, \mathrm{F})$.

M51 (units assicated with M50) (C, PF). 
Size categories $\underline{1}$

(Metric tons of metal or mineral contalned unless otherwise specifled)

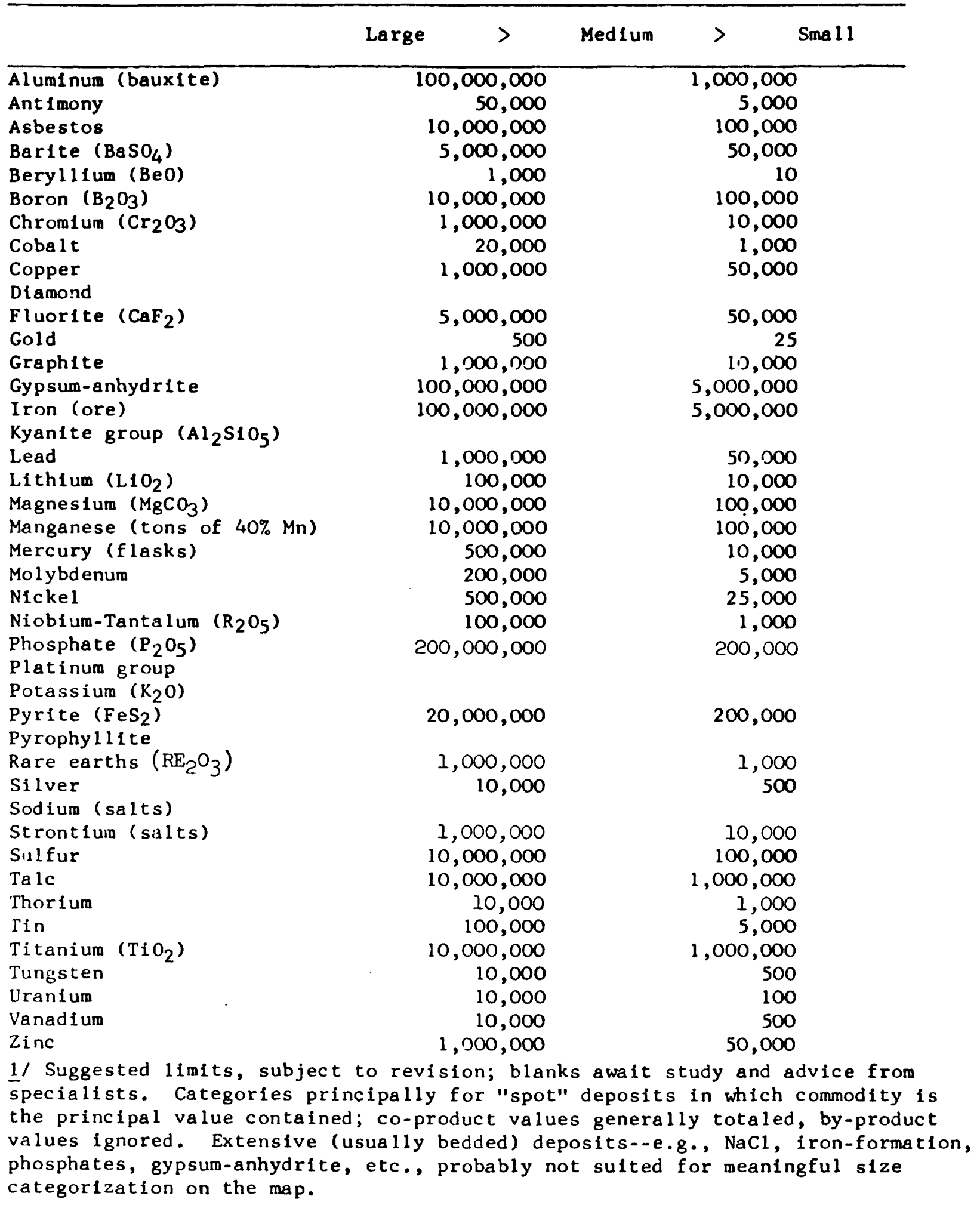

FIGURE 2.-Size of deposit categories for the major metals. Adapted from Guild (1968). 
M60 Maximum thickness (numeric field).-

This entry applies mainly to low-dipping deposits. (N, F).

M61 (units associated with M60) (C, PF).

The following four fields (M70, M80, M90, and M100) refer to specific measurements such as N. $20^{\circ}$ E., or a generalized regional trend, such as $\mathrm{NE}$.

Mro Strike of orebody

M80 Dip of orebody

M90 Plunge of orebody

M100 Direction of plunge

M110 Comments (description of deposit).-

Comments relating to the description of the deposit.

\section{DESGRIPTION OF WORKINGS}

M120 Surface.-Indicates that the workings are on the surface. (L).

M130 Underground.-Indicates that the workings are underground. (L).

M140 Surface and underground.-Indicates that the workings are both on the surface and underground. (L).

\section{Description of underground workings}

M160 Depth of workings below surface (numeric field).-Depth from the surface to the lowest workings (ground surface $=0$ ). $(\mathrm{F}, \mathrm{N})$.

M161 (units associated with M160) (C, PF). M1\%0 Length of workings (numeric field).The aggregate length of the subsurface workings. $(\mathrm{F}, \mathrm{N})$.

M1i1 (units associated with M170) (C, PF). Description of open workings (surface and underground).-Refers to surface quarries, open-pit mining, and to large underground stopes, rooms, and so on.

M190 Overall Length of Mined Area (numeric field) $(\mathrm{F}, \mathrm{N})$.

M191 (units associated with M190) (C, PF). M200 Overall width of mined area (numeric field) $(\mathrm{F}, \mathrm{N})$.

Mथ01 (units associated with M200) (C, PF). M210 Overall area (numeric field) (F, N). $M 211$ (units associated wtih M210) (C, PF). M220 Comments (description of workings). -This field is now used solely for comments on "Description of Workings." Prev- iously it was used for comments on both "Description of Deposit" and "Description of Workings."

\section{PRODUCTION}

PROD Production.-This label is used to indicate that there is an entry in one or more of the production tables or that one or more of the following labels have been used: YES, NO, LGE, MED, SML, D8, D9, D10. It also generates the header line for the Production section. (L).

YES. Yes.-Ore or any of the commodities listed are being or have been produced. (L). NO No Production.-No production present or past has occurred as of the date reported. (L).

LGE Large production (L).

MED Medium production (L).

SML Small production.-The reporter uses his own judgment in describing production as large, medium, or small. (L).

\section{ANNUAL PRODUCTION (ORE AND COMMODITIES)}

Seven lines (numbered 1-7) are provided in this table for annual production information for ore and for as many as six commodities; one line is available for each item reported. The lines are formatted as follows:
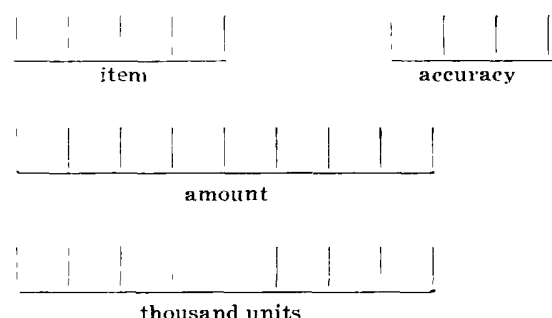

thousand units
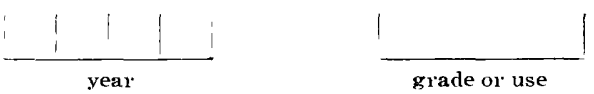

D1-Dr Item and accuracy.-Commodity codes from Commodity Codes (List E, p. B26-B28) are entered in the first four spaces. The last three spaces are intended to provide an indication of whether the production figures are accurate, estimated, or an average. If figures are not available, the reporter should indicate whether amounts are small, medium, large. See Accuracy (List G, p. B28) for these codes. (F, C). 
$D 1 A-D r A$ Amount (numeric field.)-Production figures are reported in thousands of units. Therefore, the figure given must be multiplied by 1,000 to obtain the production figures in single units. $(\mathrm{F}, \mathrm{N})$.

Format:

Example: 0004.253 on printout would represent 4253 as an actual figure in single units.

D1B-DrB Thousand units.-These fields contain the units associated with the amount field. The reporter may have repeated the same commodity but with different production figures and different units on another line of the table. Units should be abbreviated as shown in Measurement Units (List $\mathrm{H}$, p. B28). In rare records, figures greater than $99,999,999,000$ may be entered. Then, millions of units will be entered in the "thousand units" field. ( F, C) .

$\begin{array}{ccc}\text { Example: } & \text { (amount) } & \text { (thousand units) } \\ \text { D1A } & 00000234 & \text { D1B MIL TONS }\end{array}$

would represent 234 thousand million tons or $234,000,000,000$ tons.

D1C-DrC Year.-These fields of four spaces each contain the year of production, if known. On earlier versions of the CRIB input forms, the production years were entered in a field, D8, called "Production Years." This field is no longer used, and the entries have been moved into their proper places in various production tables. However, some records may still contain production years in field D8 instead of in fields D1C-D7C. $(\mathrm{F}, \mathrm{N})$.

$D 1 D-D \sim D$ Grade or use.-An unformatted field containing the grade of the item. Some records may show a particular end use. Grade refers primarily to ore grade and should include the grade of the different metals in the ore.

Example: $\mathrm{D} 1 \mathrm{D}<11.5 \% \mathrm{~PB} ; 250 \mathrm{OZ} / \mathrm{TON}$ $\mathrm{AG} ; 5$ \% $\mathrm{CU} ; 0.1$ \% $\mathrm{AU} ; \mathrm{ZN}$ UNKNOWN>

Where the specific grade of the ore is unknown, the reporters have been asked to list the principal commodities (metals) in the ore.
CUMUlative PRODUCTION

(ORE, COMMOD., CONC., OVERBUR.)

Nine lines (numbered 8-16) are provided in this table for information on cumulative production of ore and commodities and concentrates, and on overburden removed. This table may show a total cumulative production, production during a given time segment of two or more years, or intermittent production across several time segments.

The same general format is used here as in the previous table for Annual Production, except that a range of years may appear in fields G7C-G15C to indicate the range of years used for the cumulative production figures.

Gr-G15 Item and accuracy.-Similar to entries under D1-D7 (see p. B15). (F, C).

GrA-G15A Amount (numeric field) (8 spaces). -Cumulative production figures are reported here in thousands of units. (See example under D1A-D7A on p. B16). (F, N).

$G \pi B-G 15 B$ Thousand units.-These fields define the units associated wtih the amounts column. (See example and explanation under D1BD7B on p. B16). (F, C).

GrC-G15C Years.-These fields contain the range of years of the cumulative production. $(\mathrm{F}, \mathrm{N})$.

G7D-G15D Grade or use.-The grade or use, if known. In the records of overburden removed, grade, or use does not apply. The grade is taken as the average across the span of years shown (see example under D1D-D7D, p. B16).

\section{ANNUAL PRODUCTION (OVERBURDEN AND CONCENTRATES)}

Seven lines (numbered 17-23) are provided in this table for information on annual production of concentrates and annual removal of overburden. This table is similar to the Annual Production (ore and commodities) table except that nine spaces are allowed in the "item" field instead of four.

$P 1-P 7$ Item and accuracy.-Similar to entries under D1-D7 (see p. B15), except that the codes used will be OVB (overburden) or CON (concentrates). ( $\mathrm{F}, \mathrm{C})$.

P1A-PrA Amount (numeric field).-Annual figures for production of concentrates and removal of overburden are reported here in 
thousands of units. (See example under D1A-D7A on p. B16). (F, N).

$P 1 B-P 7 B$ Thousand units.-These fields contain the kind of units associated with the amounts column. (See examples and explanation under D1B-D7B on p. B16). (F, C).

$P 1 C-P 7 C$ Year.-These fields contain the year of production of concentrates or removal of overburden. $(\mathrm{F}, \mathrm{N})$.

P1D-PrD Grade, remarks.-The grade of the concentrates. Grade does not apply to overburden. Some records may contain short remarks.

The following three fields (D8, D9, D10) may refer to items in any of the three production tables.

Ds Production years.-This field is discontinued. However, entries in this field are on older records. Production years are now being entered in D1C-D7C, G7C-G15C, P1CP7C.

D9 Source of information.-This field is for notations on the source $(s)$ of the information in the production tables. In many records, the complete reference (s) appear under General References (labels F1-F4) in the same record. If item numbers appear here, they refer to the individually numbered lines of the production tables.

D10 Production comments.-Explanatory notes that clarify or add information to the entries in the production tables. Item numbers may be used here also.

\section{MINERAL RESERVES AND RESOURCES}

The classification of mineral resources used in the CRIB file follows closely that devised by McKelvey (1972). Several refinements have since been published (Brobst and Pratt, 1973; U.S. Geological Survey, 1975; U.S. Bureau of Mines and U.S. Geological Survey, 1976), but these have not changed the basic classification. The only modifications made in the CRIB file to McKelvey's original scheme are the substitution of "Measured," "Indicated," and "Inferred" reserves for the terms "Proved," "Probable," and "Possible" reserves. The basic elements of this slightly modified classification are shown in figure 3 .

Three tables plus certain additional fields are used to computerize the information on the

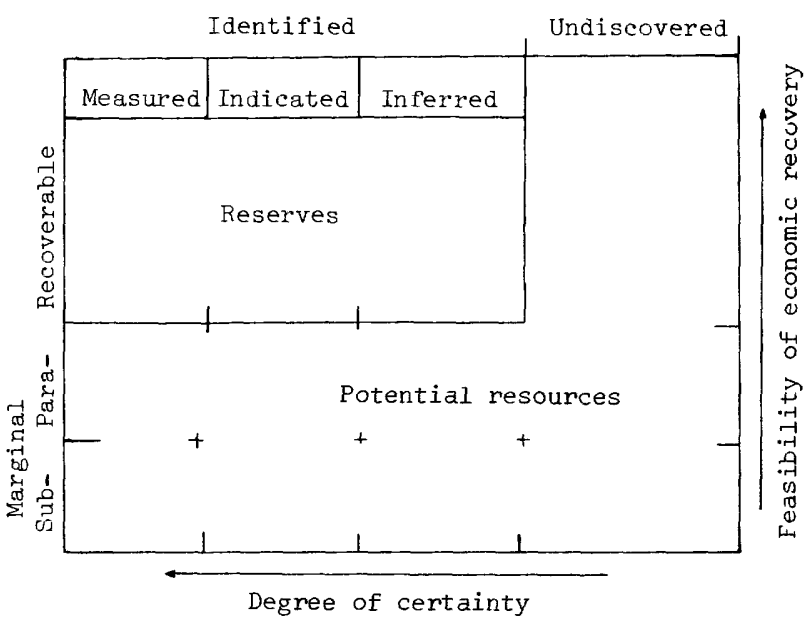

Figure 3.-Diagram showing the classification of reserves and resources as used in the CRIB file.

resources of a given mineral deposit. Information in the table RESERVES AND POTENTIAL RESOURCES represents the total current resources of the deposit, that is, the entire area of the box shown in figure 3 . The table RESERVES ONLY represents the area of the upper left corner of the box, and the table POTENTIAL RESOURCES represents the remaining area of the box, that is, those marginal and undiscovered resources that are not classified as reserves. Detailed discussion of the concept of mineral reserves and resources and of the classification of mineral resources is found in Brobst and Pratt (1973) and U.S. Bureau of Mines and U.S. Geological Survey (1976).

The tables RESERVES ONLY and POTENTIAL RESOURCES provide for a separation of reserve data from data on potential resources. Separate treatment of these two aspects of mineral resources represent an important objective of any mineral resources appraisal or inventory. Such information, however, is not always available.

\section{RESERVES AND POTENTIAL RESOURCES}

Six lines (numbered 1-6) are provided in this table for information on reserves plus potential resources of the given ore deposit or mineral locality. One line is used for each item reported. The fields in each line are similar to those previously described in the production tables. These fields are listed below:

E1-E6 Item and accuracy $(\mathrm{F}, \mathrm{C})$.

E1A-E6A Amount (numeric field) (F, N). 
E1B-E6B Thousand units (F, C).

E1C-E6C Year of estimate (F, N).

E1D-E6D Grade or use

Er Source of information.-Short notations on source of information about the reserves and potential resources. A more complete reference might be found under General References (labels F1-F4) in the same record.

E8 Comments.--Explanatory notes are entered here, in particular, notes on the general outlook for finding more ore or developing the ore already there. In some records, the key words, "STUDY NEEDED," may be entered here to indicate that the reporter believes that the locality may have definite potential, warranting additional study of the locality.

\section{RESERVES ONLY}

Six lines (numbered 1-6) are provided in this table for information on reserves only, one line for each item reported.

Reserves may be treated as a single undedefined class in the table, or they may be divided into measured, indicated, and inferred reserves. If the latter is done, the class of reserves will appear in the "Grade or use" fields. The following entries are similar to these in the previously described tailes.

H1-H6 Item and accuracy (F, C).

H1A-H6A Amount (numeric field) (F, N).

$H 1 B-H 6 B$ Thousand units $(\mathrm{F}, \mathrm{C})$.

H1C-H6C Year of estimate $(\mathrm{F}, \mathrm{N})$.

H1D-H6D Grade or use

Hr Comments

Hs Source of information

\section{POTENTIAL RESOURCES \\ (EXCLUSIVE OF RESERVES)}

Six lines (numbered 1-6) are provided in this table for information on potential resources, one line for each item reported. "Potential resources" refers to undiscovered deposits or to those identified reserves that at present are not recoverable. The following entries are similar to those in the previously described tables.

J1-J6 Item and accuracy $(\mathrm{F}, \mathrm{C})$.

$J 1 A-J 6 A$ Amount (numeric field) (F, N).

$J 1 B-J 6 B$ Thousand units $(\mathrm{F}, \mathrm{C})$.
J1C-J6C Year of estimate $(\mathrm{F}, \mathrm{N})$.

J1D-J6D Grade or use

J7 Comments

J8 Source of information

\section{GEOLOGY AND MINERALOGY}

The entries on geology and mineralogy are those likely to bear some geological relationship to mineral deposits. Several entries (K1, K2, K3, N30, N35, N40, N45, N50, N55, N60, N65) have a 10-space subfield for geologic ages allotted at the beginning of the entry. The codes for these ages will be found in Authorized Age Abbreviations (List O, p. B30). On early records, however, the geologic ages were placed as complete words at the end of the entry.

Kr General geological environment.-A specialpurpose field used only in records obtained from a tape file on metallogenic map data on North America. (NS).

K1 Age/names of host rocks-The geologic ages and the rock types associated with the ore are entered here. (PF. C).

K2 Ageinames of associated igneous rocks.Ages and names of igneous rocks associated with the deposit. If the host rock itself is igneous, this field may show the same information as is in $\mathrm{K} 1$.

K3 Age of mineralization.-The geologic age during which the mineralization took place. $(\mathrm{F}, \mathrm{C})$.

K. Pertinent mineralogy.-This field provides for the entry of mineralogic information on minerals other than ore minerals.

K5 Important ore control or locus.-One or more general or specific ore controls may be recorded here.

K6 Geological descriptive notes.-Discontinued field used on early records for comments on the geology and mineralogy section. On later records, these comments appear in the comments field N85. (D, NS).

\section{GEOLOGY (SUPPLEMENTARY INFORMATION) REGIONAL GEOLOGY}

N5 Major regional structures.-This field may include a description of any significant large folds, faults, or other regional structures or trends. 
N10 Regional trends.-Discontinued field used on early records. Now combined with N5 (Major Regional Structures). (D, NS).

N15 Tectonic setting.-Shield, geosyncline, platform, piedmont, or descriptive terms of other large-scale tectonic features may be entered here.

N20 Major lithologic/stratigraphic units.-Discontinued field. Entries may appear in early records, but the label is no longer in use. (D, NS) .

N25 Comments.-Discontinued field. Entries may appear in early records, but now comments are entered in N85.

\section{LOCAL GEOLOGY}

Age, names of formations or rock types

N30, N35, N40, N45.-Each of the four lines provided here has space for recording the ages and names of formations and rock types. Ages, coded from Authorized Age Abbreviations (List O, p. B30), should appear as the first subfield of each line. In older records, however, the geologic ages were placed at the end of each line.

( $\mathrm{PF}, \mathrm{C})$.

Age!names of igneous units or rock types

N50, N55, N60, N65.-Each of the four lines provided here has space for the ages and names of igneous units or rock types. The placement of the geologic ages is the same as in the previous four fields. (PF, C).

Nro Significant local structures.-This field is for the description of any significant local structures that characterize the area.

N75 Significant alteration.-Descriptive text on alteration may appear here if alteration has a bearing on the given deposit.

N80 Geological processes of concentration or enrichment.-Additional information may be entered here on the basic causes of concentration or enrichment of the given deposit.

\section{COMMENTS (GEOLOGY AND MINERALOGY)}

N85 Comments (geology and mineralogy).Any information concerning the geology and mineralogy that has not been previously shown may appear in this field.

\section{GENERAL COMMENTS}

GEN General comments.-This field is for any kind of general information about the deposit that has not been placed in other fields or that could be an elaboration on another field.

\section{GENERAL REFERENCES}

$F 1, F \stackrel{\sim}{\sim} F 3, F 4$ (4 fields).-These four fields contain bibliographic references. Reporters are encouraged to follow the standard U.S. Geological Survey arrangement (author's last name, author's initials, date of publication, title of article, name of periodical). However, this arrangement has not always been followed. Therefore references appear in a variety of ways. More than one reference may be stored under each label; this has been done in some records, usually under label F4.

\section{INDEX LIST OF DATA ITEMS}

This section consists of an index list of labels (fields) arranged in label sequence for quick reference. Each entry contains the label, item description, and the "characteristics codes" as described in the previous section. Approximately 392 labels are available for search purposes.

\section{A}

Form A used as source document (NS, L, D).
Ash ( F, N).

Deposit name.

Synonym name (s).

Present or last owner.

Present or last operator.

Status of exploration or development (C, F).

Property is active ( $\mathrm{L})$.

Property is inactive (L).

Mining district/area/subdistrict.

Subdistrict (NS).

Continent or global area (NS).

Country code (C, F).

State code (coded and formatted only for the United States and Canada) (C, F).

County.

Congressional District (NS).

Drainage area $(\mathrm{PF}, \mathrm{C})$.

Physiographic province (PF, C).

Land classification (C, F).

Name of forest (NS).

Latitude (F). 
A 80

A81

A82

A 83

A90

A91

A92

A 100

A 107

A 110

A 120

A 130

B

BTU BYPROD

B10

B30

B40

B50

B51

CARB COPROD

C10

C20

C21

C22

C23

C30

C40

C41

C42

C42A

C42B

$\mathrm{C} 42 \mathrm{C}$

C42D

C42E

$\mathrm{C} 42 \mathrm{~F}$

C42G

C43

C44

C45
State $\mathrm{X}$ coordinate $(\mathrm{N}, \mathrm{F})$.

State $\mathrm{Y}$ coordinate $(\mathrm{N}, \mathrm{F})$.

State zone number (N, F).

$\mathrm{X}$ (map coordinate for $1: 250,000$-scale map) (N, NS) .

$Y$ (map coordinate for $1: 250,000$-scale map) (N, NS).

$\mathrm{X}$ (map coordinate for $1: 63,360$-scale map) (N, NS).

Y (map coordinate for $1: 63,360$-scale map) (N, NS).

Township (s) (F).

Range ( $\mathrm{s}$ ) (F).

Section (s) (F).

Longitude (F).

Meridian.

Position from nearest prominent locality.

Location comments.

Quadrangle number or name.

1 : Second quadrangle scale ( $F, N, N S)$.

Second quadrangle number or name (NS).

1: Quadrangle scale $(\mathrm{F}, \mathrm{N})$.

Altitude (N, PF).

UTM zone number ( N, F).

UTM northing $(\mathrm{N}, \mathrm{F})$.

UTM easting ( $N, F)$.

\section{B}

Form B used as source document (NS, L, D).

BTU (N, F).

Byproduct $(F, C)$.

Record number (unique identifier) ( $F$ ).

Source (NS).

Deposit number.

File Link ID (PF).

Geologic code (NS).

\section{C}

Fixed carbon (N, F).

Coproduct $(\mathrm{F}, \mathrm{C})$.

Commodities present $(F, C)$.

Commodity specialist information (F, C).

Special field 1 (NS).

Special field 2 (NS).

Special field 3 (NS).

Ore materials (minerals, rocks, and so on).

Deposit types (PF).

Commodity subtypes or use categories.

Economic comments.

Exploration $\mathrm{M} \$(\mathrm{~N})$.

Development M\$ (N).

Expansion $M \$(N)$.

Mill $\mathrm{M} \$(\mathrm{~N})$.

Total Investments $M \$(N)$.

Mill capacity per year (thousand units) (N, F).

Year applicable (N, F).

Analytical data (general).

Source reference.

Volatile material (,$F)$.
Moisture (N, F).

Thickness of coal $(\mathrm{N}, \mathrm{F})$.

Commodity comments.

\section{D}

$\mathrm{D}$

Indicates special-purpose form used as source document (NS, L, D).

Annual production (ore and commodities)

D1-D7 Item and accuracy $(F, C)$.

D1A-D7A Amount (F, N).

D1B-D7B Thousand units $(\mathrm{F}, \mathrm{C})$.

D1C-D7C Year (F, N).

D1D-D7D Grade or use.

D8 Production years (D, NS).

D9 Source of information.

D10 Production comments.

\section{E}

Rescrues and potential resources

E1-E6 Item and accuracy $(\mathrm{F}, \mathrm{C})$.

E1A-E6A Amount ( F, N).

E1B-E6B Thousand units $(F, C)$.

E1C-E6C Year of estimate $(F, N)$.

E1D-E6D Grade or use.

E7 Source of information.

E8 Comments (reserves and potential resources) .

\section{F}

General references

F1 (First reference).

F2 (Second reference).

F3 (Third reference).

F4 (Fourth reference).

G

GEN General comments.

G1 Date (year and month) ( $F, N)$.

G2 Name (reporter) (PF).

G3 Update (s) (year and month) $(\mathrm{F}, \mathrm{N})$.

G4 By (PF).

('umulutie production fore, commod., conc., overbur.)

G7-G15 Item and accuracy (F, C).

G7A-G15A Amount (F, N).

G7B-G15B Thousand units (F, C).

G7C-G15C Years.

G7D-G15D Grade or use.

\section{H}

Reserves ouly

$\mathrm{H} 1-\mathrm{H} 6$

$\mathrm{H} 1 \mathrm{~A}-\mathrm{H} 6 \mathrm{~A}$

$\mathrm{H} 1 \mathrm{~B}-\mathrm{H} 6 \mathrm{~B}$

$\mathrm{H} 1 \mathrm{C}-\mathrm{H} 6 \mathrm{C}$

H1D-H6D

$\mathrm{H} 7$

H8
Item and accuracy $(F, C)$.

Amount (F, N).

Thousand units $(F, C)$.

Year of estimate $(F, N)$.

Grade or use.

Comments (reserves only).

Source of information. 


\section{J}

Potcntial resources (exclusive of reserves)

J1-J6

J1A-J6A

J1B-J6B

J1C-J6C

J1 D-J6D

J7

J8

K1

K2

K3

K4

K5

$\mathrm{K} 6$

K7

L

LGE

L10

L20

L30

L40

L41

L42

L43

L50

L60

L70

L80

L90

L100

L110
Item and accuracy $(\mathrm{F}, \mathrm{C})$.

Amount (F, N).

Thousand units $(F, C)$.

Year of estimate $(F, N)$.

Grade or use.

Comments (potential resources exclusive of reserves).

Source of information.

\section{K}

Age/names of host rocks (PF, C).

Age/names of associated igneous rocks (PF, C).

Age of mineralization ( F, C) .

Pertinent mineralogy.

Important ore control or locus.

Geologic descriptive notes (D, NS) .

General geological environment (NS).

\section{L}

Standard long form used as source document (NS, L, D).

Large production (L).

Year of discovery.

By whom.

Nature of discovery (F, C).

Year of first production.

Work done by USGS
(year) (type of work) (geolugist and results)

(1)

(2)

(3)

(N, C, PF).

Wark done by othar organizations

(year) (type of work) (organization and results)

(2)

(3)

(4)

(5)

(N, C, PF)

Reports available.

Exploration and development comments.

\section{$\mathbf{M}$}

$\begin{array}{ll}\text { MAJOR } & \text { Major product }(\mathrm{F}, \mathrm{C}) . \\ \text { MED } & \text { Medium production (L). } \\ \text { MINOR } & \text { Minor product (F, C). } \\ \text { M10 } & \text { Form/shape of deposit (C, PF). } \\ \text { M15 } & \text { Size of deposit (PF). } \\ \text { M20 } & \text { Depth to top (N, F). } \\ \text { M21 } & \text { Units (C, PF). } \\ \text { M30 } & \text { Depth to bottom (N, F). } \\ \text { M31 } & \text { Units (C, PF). } \\ \text { M40 } & \text { Maximum length (N, F). } \\ \text { M41 } & \text { Units (C, PF). } \\ \text { M50 } & \text { Maximum width (N, F). }\end{array}$

N45

N50

N55

N60

N65

N70

N75

N80

N85

OCCUR

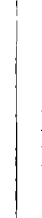

Units (C, PF).

Maximum thickness (N, F).

Units (C, PF).

Strike of orebody.

Dip of orebody.

Plunge of orebody.

Direction of plunge.

Comments (description of deposit).

\section{Surface (L).}

Underground (L).

Surface and underground $(L)$.

Depth of working below surface $(\mathrm{N}, \mathrm{F})$.

Units (C, PF).

Length of workings $(\mathrm{N}, \mathrm{F})$.

Units (C, PF).

Overall length of mined area $(\mathrm{N}, \mathrm{F})$.

Units (C, PF).

Overall width of mined area $(\mathrm{N}, \mathrm{F})$.

Units (C, PF).

Overall area $(\mathrm{N}, \mathrm{F})$.

Units (C, PF).

Comments (description of workings).

\section{$\mathbf{N}$}

No production (L).

Major regional structures.

Regional trends (D, NS).

Tectonic setting.

Major lithologic/stratigraphic units (D, NS).

Comments (on regional geology (D, NS) .

Alfe names of formatum or rock typers

(1)

(4)

(PF, C).

1ste nomes of ignoous units or rock types

(1)

(2)

(3)

(4)

(PF, C).

Significant local structures.

Significant alteration.

Geologic processes of concentration or enrichment.

Comments (geology and mineralogy).

\section{O}

Occurrence (F, C).

\section{$\mathbf{P}$}

POTEN Potential (F, C).

PROD Production (Indicates that production information is available) (L).

Annual production (overburden and concentrates)

P1-P7 Item and accuracy (F, C).

P1A-P7A Amount (F, N).

P1B-P7B Thousand units $(F, C)$. 
P1C-P7C Year (F, N).

P1D-P7D Grade, remarks.

\section{$S$}

S

SML

SUL

$\mathrm{U}$

USGS

YES

Sulfur (N, F).

\section{$\mathbf{U}$}

\section{$\mathbf{Y}$}

Special short form used as source document (NS, L, D).

Small production $(\mathrm{L})$.

Indicates updated record ( $L)$.

Country organization USGS (L).

Yes (there is or has been production) (L).
CODE LISTS

LIST A

RECORD TYPE

(Discontinued)

LIST B

STATUS OF EXPLORATION OR DEVELOPMENT ciode

1 Occurrence.-Single-point information from outcrop, shallow pit, or isolated drillhole.

2 Raw prospect.-Two-dimensional information. Information exists on length and width from surface trenches, shallow adits, or scattered shallow drilling. Depth unknown or uncertain.

3. Developed prospect.-Three-dimensional information. Information exists on length, width, and depth from systematic drillhole patterns, mine workings, mapping, or other work.

4 Producer.-Mine or district that is producing or that has produced. 
Af

AFGHANISTAN

ALBANIA

ALGER IA

AMERICAN SAMOA

ANDORRA

ANGOL A

ANTARCTICA

ANTIGUA

ARGENTINA

ASHMORE ANO CART IER ISLANOS

AUSTRALIA

AUSTR IA

B AHAMAS

BAHRA IN

B ARBADOS

BELGIUH

B ERMUOA

BHUTAN

B OLIVIA

BOTSWANA

BOUVET ISLAND

BRAZIL

BRITISH HONDURAS

BRITISH INOIAN OCEAN TERR.

BRITISH SOLDMDN ISLANOS

BRITISH VIRGIN ISLANDS

B RUNE I

BULGARIA

BURHA

BURUNDI

CAMBODIA

CAMERDDN

CANAOA

CANAL ZONE

CANTON AMO ENDERBURY I SLANOS

CAPE VERDE

CAYMAN ISLANDS

CENTRAL AFRICAN REPUBLIC

CENTRAL AND SOUTHERM LINE ISLANDS

CEYLON

CHAD

CHILE

CHINA MAINLAND

CHINA,REPUBLIC OF

CHRISTMAS ISLAND

COCOS I SLANDS

COL OM BIA

COMORO ISLANOS

CONGO (KINSHASA)

CONGO REPUBL IC
COOK ISLANOS

COSTA RICA

CUBA

CYPRUS

C ZECHOSLOYAKIA

DAHOMEY

DENMARK

DOMINICA

DOMINICAN REPUBLIC

EAST GERHANY

ECUADOR

EL SALVADOR

EQUATORIM GUINEA

ETHIOPIA

FAEROE ISLANOS

FALKL AND ISLANOS

F I JI

F INLAND

FRANCE

FRENCH GUIANA

FRENCH PQL YNESI A

FRENCH SOUTHERN AND ANTARCTIC LANDS

FRENCH TERRITORY OF AFARS AND ISSAS

GABON

GAMBIA

GAZA STRIP

GHANA

GIBRALTAR

GILBERT ANO ELLICE ISLANOS

GREECE

GREENLAND

GRENADA

GUADELOUPE

GUAM

GUATEMALA

GUINEA

GUYANA

HAITI

HEARO AND MCOONALD ISLANDS

HONOURAS

HONG KONG

HUNGARY

I CELAND

INDIA

INDONES IA

IRAN

IRAQ

IRAO-SAUDI ARABIA NEUTRAL ZONE

I RELAND

I SRAEL 
CODE

COUNTRY NAME

I TALY

I VORY COAST

JAMAICA

JAN MAYEN

JAPAN

JOHNSTON ATOLL

JORDAN

KENYA

KOREA, NORTH

KOREA, SOUTH

KUWAIT

LAOS

LEBANON

LESOT HO

LIBERIA

LIBYA

LIECHTENSTEIN

LUXEMBOURG

MACAO

MADAGASCAR

MALAWI

MALAYSIA

MALDIVES

MALI

MAL TA

MART I NI CUE

MAUR I TANIA

MAURITIUS

MEXICO

MIDWAY ISLANDS

MONACD

MONGOLIA

MONTSERRAT

MOROC CD

MOZAMBI QUE

MUSCAT AND OMAN

NAMI BIA

NAURU

NEPAL

NETHERLAMDS

NETHERL ANOS ANT ILLES

NEW CALEDONI A

NEW HEBR IDES

NEW ZEALAND

NICARAGUA

NIGER

NIGER IA

NIUE

NORFOLK ISLAND

NORWAY
CODE

PK

PN

PP

PA

PE

RP

$P C$

PD

PU

PT

RQ

QA

RE

RO

ra

SM

TP

SA

SG

SK

SN

SO

SF

RH

YS

UR

SP

SS

ME

SC

SH

ST

SB

VC

SU

SV

SO

SW

S2

SY
COUNTRY NAME

\section{PAKISTAN}

PANAMA

PAPUa AND new gUINEA

PARACEL ISLANDS

PARAGUaY

PERU

PHILIPPINES

PITCAIRN I SLAND

POLAND

PORTUGAL

PORTUGUese GUINEA

PORTUGUESE TIMJR

PUERTO RICO

oATAR

REUNION

ROMANIA

RWANDA

RYUKYU I SLANDS, SOUTHERN

SAN MARINO

SAO TOME AND PRINCIPE

SAUDI ARABIA

SENEGAL

SEYCHELLES

SIERRA LEONE

SIKK IM

SINGAPORE

SOMAL IA

SOUTH AFRICA

SOUTH-WE ST AFRICA

SOUTHERN RHODESIA

SOUTHERN YEMEN

SOVIET UNION

SPAIN

SPANISH SAHARA

SPANI SH TERR. IN N. MOROCCO

SPRATLY ISLAND

ST. CHR ISTOPHER-NEVIS-ANGUILLA

ST. HELENA

ST. LUCIA

ST. PIERRE AMD MIQUELON

ST. VINCENT

SUDAN

SURINAM

SVALBARD

SWAN I SLANOS

SWAZIL AND

SWEDEN

SWI TZERL AND

SYRIA

TANZANIA 
CODE

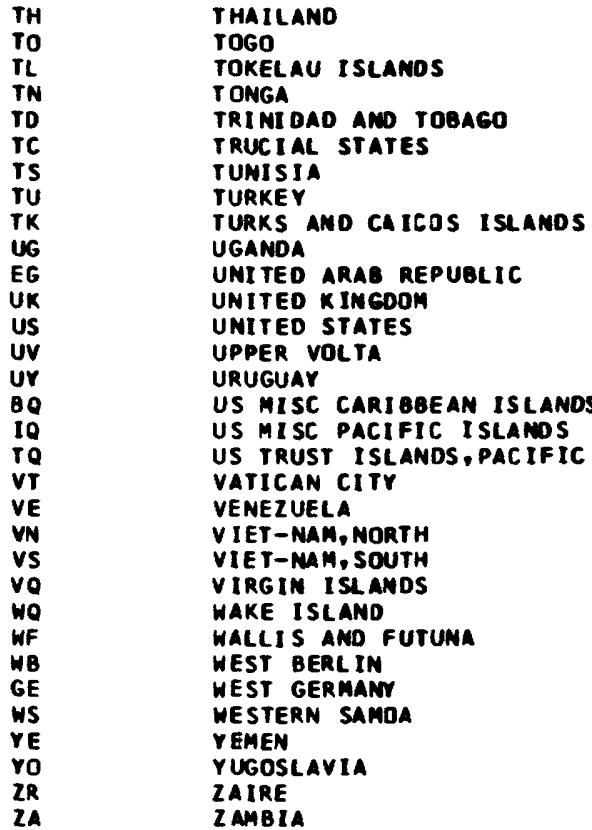


LIST D

\section{STATE CODES FOR U.S. AND PROVINCE CODES FOR CANADA}

The following codes are reserved for possible future use: 03, American Samoa; 07, Canal Zone; 14, Guam; 43, Puerto Rico; and 52, Virgin Islands.

\begin{tabular}{cl} 
Code & \multicolumn{1}{c}{ State } \\
01 & Alabama \\
02 & Alaska \\
04 & Arizona \\
05 & Arkansas \\
06 & California \\
& \\
08 & Colorado \\
09 & Connecticut \\
10 & Delaware \\
11 & District of Columbia \\
12 & Florida \\
& \\
13 & Georgia \\
15 & Hawaii \\
16 & Idaho \\
17 & Illinois \\
18 & Indiana \\
& \\
19 & Iowa \\
20 & Kansas \\
21 & Kentucky \\
22 & Louisiana \\
23 & Maine \\
& \\
24 & Maryland \\
25 & Massachusetts \\
26 & Michigan \\
27 & Minnesota \\
28 & Mississippi \\
& \\
& \\
&
\end{tabular}

\begin{tabular}{cl} 
Code & \multicolumn{1}{c}{ State } \\
29 & Missouri \\
30 & Montana \\
31 & Nebraska \\
32 & Nevada \\
33 & New Hampshire
\end{tabular}

4 New Jersey

35 New Mexico

36 New York

37 North Carolina

38 North Dakota

39 Ohio

40 Oklahoma

41 Oregon

42 Pennsylvania

44 Rhode Island

45 South Carolina

46 South Dakota

47 Tennessee

48 Texas

49 Utah

50 Vermont

51 Virginia

53 Washington

54 West Virginia

55 Wisconsin

56 Wyoming

\begin{tabular}{cl} 
codr & \multicolumn{1}{c}{ Province } \\
01 & Newfoundland-Labrador \\
02 & Nova Scotia \\
03 & Prince Edward Island \\
04 & New Brunswick \\
05 & Quebec \\
06 & Ontario \\
07 & Manitoba \\
08 & Saskatchewan \\
09 & Alberta \\
10 & British Columbia \\
11 & Yukon Territory \\
12 & Mackenzie District, NWT \\
13 & Franklin District, NWT \\
14 & Keewatin District, NWT \\
& $\quad$ LIST E \\
& COMMODITY CODES
\end{tabular}

Note.-For commodities not on this list, contact the CRIB representative in Reston, Denver, or Menlo Park.
ALM
Alum
$\mathrm{AL}$
Aluminum (general)

AS

ASB

BIT

CLY 4

BA

CLY1

BE

BI

COA2

BIT

CL Y 6

B

BRI

BR

MG

STN2

CD

CA

C

CAR

\section{CER}

CE

CS

CL

CR

CLY

CLY1

CLY2

CLY3

CLY4

CLY5

CLY6

CLY7

COA

COA1

$\mathrm{COA} 2$

COA3

$\mathrm{COA} 4$

$\mathrm{CO}$

NB

$\mathrm{CON}$

$\mathrm{CU}$

COR

DIA

DIT

STN2

DOL

DOL1
Bauxite

Aluminum (from other source materials)

Alunite

Amber

Anhydrite, gypsum

Antimony

Arsenic

Asbestos

Asphalt (see Bitumens)

Ball clay

Barium, Barite

Bentonite

Beryllium

Bismuth

Bituminous coal

Bitumens (includes asphalt)

Bloating material (includes clay, shale, slate)

Boron-Borates

Brines/salines (see also Evaporites, Sodium, Halite)

Bromine

Brucite (see Magnesium)

Building stone (see under Stone)

Cadmium

Calcium (see also Carbonates, Limestone, Marble, Stone)

Carbon

Carbonates (see also Calcium, Dolomite, Limestone, Marble, Marl, Shell, Stone, Magnesium)

Cement rock (natural)

Cerium

Cesium

Chlorine

Chromium

Clay (general)

Bentonite

Fuller's earth

Kaolin or kaolinitic clay (includes highalumina clay)

Ball Clay

Fire clay (refractory)

Bloating material (includes clay, shale, slate)

Coal

Common brick clay

Anthracite

Bituminous

Sub-bituminous

Lignite

Cobalt

Columbium (see Niobium)

Concentrate

Copper

Corundum

Diamond

Diatomite

Dimension stone (see under Stone)

Dolomite (general) (see also Carbonates, Stone, Magnesium, Marble)

Utra-pure dolomite $\left(\mathrm{MgCO}_{:} \cdot \mathrm{CaCO}>97\right.$ percent) 
High-magnesian dolomite $(\mathrm{MgCO} \cdot \mathrm{CaCO}$ $>95$ percent)

\begin{tabular}{ll} 
EMY & Enery \\
EVA & Evaporites (see also Brine, Sodium, Halite) \\
FLD & Feldspar \\
CLY5 & Fire clay (refractory) \\
F & Fluorine, Fluorite \\
$\quad$ Fl & Fluorine gas \\
CLY2 & Fuller's earth \\
GA & Gallium \\
GAR & Garnet \\
GAS & Gas (natural) \\
GEM & Gemstones \\
GE & Germanium \\
GLA & Glauconite \\
AU & Gold \\
GRT & Granite, Granitic gneiss \\
GRF & Graphite \\
SDG & Gravel (see Sand and gravel) \\
GYP & Gypsum, Anhydrite \\
HF & Hafnium \\
HAL & Halite ( see also Sodium, Evaporites, Brine) \\
HE & Helium \\
H & Hydrogen \\
IN & Indium \\
I & Iodine \\
IR & Iridium \\
FE & Iron \\
CLY3 & Kaolin or kaolinitic clay (includes high- \\
& \multicolumn{1}{c}{ alumina clay) }
\end{tabular}

KYN Kyanite, Sillimanite, Andalusite, Dumortierite

$\begin{array}{ll}\text { LAT } & \text { Laterite } \\ \text { PB } & \text { Lead } \\ \text { COA4 } & \text { Lignite } \\ \text { LST } & \text { Limestone (general) (see also Carbonates } \\ & \quad \text { Calcium, Marble, Stone) } \\ \text { LST1 } & \text { Ultra-pure limestone (CaCO }>97 \text { percent) } \\ \quad \text { cent) } & \text { High-calcium limestone }(\mathrm{CaCO}:>95 \text { per- } \\ & \text { cent) }\end{array}$

\section{LI}

LWA

MGS

MG

MN

\section{Lithium}

Lightweight aggregate (see also Bloating material under Clay, Vermiculite, Perlite, Pumice, Stone)

Magnesite

Magnesium (includes Brucite) (see also Carbonates, Dolomite, Marble, Stone, Magnesite)

MBL Marble (see also Carbonates, Dolomite, Limestone, Magnesium, Stone)

$\begin{array}{ll}\text { HG } & \text { Mercury } \\ \text { MIC } & \text { Mica } \\ \text { MIC1 } & \text { Sheet mica } \\ \text { MIC2 } & \text { Scrap mica } \\ \text { MIC3 } & \text { Flake mica } \\ \text { MPG } & \text { Mineral pigments } \\ \text { MO } & \text { Molybdenum } \\ \text { MON } & \text { Monazite } \\ \text { NI } & \text { Nickel } \\ \text { NB } & \text { Niobium (Columbium) } \\ \text { N } & \text { Nitrogen-nitrates }\end{array}$

Osmiuntiridium (osmiridium)

Oil (s€e Petroleum)

Oil sands

Oil shale

Olivine

Ore

Osmium

Overburden

Oxides

Oxygen

Palladium

Peat

Perlite

Petroleum

Phosphorus-phosphates

PT Platinum

PGM Platinum group metals

K Potassium

PUM Pumice

PYR Pyrite

PYR1 Pyrrhotite

PYF Pyrophyllite

QTZ Quartz (see also Sandstone, Silica)

Quartzite/quartzose sandstone (see sandstone)

RA Radium

RAE Rare earths

RAM Radioactive materials

RE Rheniun

RH Rhodium

RB Rubidium

RU Ruthenium

BRI Salines (see Brines)

BRI Salt (see Brines, Salines, Sodium, Halite)

SDG Sand and gravel

SAM Sand, molding

SST Sandstone (see also Silica, Stone, Quartzite)

SAP Saprolite

SC Scandium

SE Selenium

SHL Shale

SIL Silica (see also Quartz, Quartzite, Sandstone)

AG Silver

SLA Slate (see also Stone)

NA Sodium (see also Evaporites, Halite, Brine)

STN

STN1

Stone

Crushed/broken stone material (includes road metal, riprap, scoria, slag, clinker, baked clay, red dog)

STN2 Dimension or building stone (see also Calcium, Carbonates, Dolomites, Limestone)

SR Strontium

COA3 Sub-bituminous coal

SUL Sulfides

S Sulfur

SLF Sulfuric acid

TLC Talc, Soapstone

TA Tantalum 


$\begin{array}{ll}\text { TE } & \text { Tellurium } \\ \text { TL } & \text { Thallium } \\ \text { TH } & \text { Thorium } \\ \text { SN } & \text { Tin } \\ \text { TI } & \text { Titanium } \\ \text { W } & \text { Tungsten } \\ \text { UNF } & \text { Unidentified commodity } \\ \text { U } & \text { Uranium } \\ \text { V } & \text { Vanadium } \\ \text { VRM } & \text { Vermiculite } \\ \text { VOL } & \text { Volcanic materials (ash, cinders) } \\ \text { WOL } & \text { Wollastonite } \\ \text { YT } & \text { Yttrium } \\ \text { ZEO } & \text { Zeolites } \\ \text { ZN } & \text { Zinc } \\ \text { ZN1 } & \text { Zinc oxide } \\ \text { ZR } & \text { Zirconium }\end{array}$

\section{LIST F}

\section{DEPOSIT TYPES (Examples)}

This list is not exhaustive. Other deposit types may be used as needed.

Alkalic-mafic intrusive
Bedded
Chemical sediment
$\quad$ (except evaporites)
Clastic sedinentary rock
Concordant igneous
Contact metasomatic
Disseminated
Evaporites
Gossan
Laterite
Lens
Massive sulfides
Metamorphic
Metamorphosed bed

Pegmatite

Pipe

Placer

Replacement

Secondary enrichment

Skarn/greisen

Stratabound

Stratiform

Stockwork

Sulfide segregation

Unconsolidated sediments

Vein/shear zone

Volcanic

Weathering residual

\section{LIST G}

\section{ACCURACY}

$\begin{array}{ll}\text { cod. } & \\ \text { AVG } & \text { Average figures } \\ \text { ACC } & \text { Accurate figures } \\ \text { EST } & \text { Estimate } \\ \text { SML } & \text { Small } \\ \text { MED } & \text { Medium } \\ \text { LGE } & \text { Large }\end{array}$

\section{LIST H}

\section{MEASUREMENT UNITS}

If none of the units apply, insert the name of the units that pertain to the commodity in question. Millions of units can be expressed by adding the prefix MIL as shown in some of these entries. Do not use $\$$ (dollars) as units.

\begin{tabular}{ll} 
Ucres & \multicolumn{1}{c}{ Abbreviation: } \\
Barrels & ACRES \\
Cubic feet & BBL \\
Cubic meters & CF \\
Cubic yards & CM \\
Feet & CY \\
Flasks & FT \\
Grams & FL \\
Kilograms & G \\
Kilometers & KG \\
Long dry tons & KM \\
Long tons & LDT \\
Long-ton units & LT \\
Meters & LTU \\
Metric tons & M \\
Miles & MET TONS \\
Million cubic feet & MI \\
Million pounds & MIL CF \\
Million tons & MIL LB \\
Ounces & MIL TONS \\
Pounds & OZ \\
Short dry tons & LB \\
Short tons & SDT \\
Short-ton units & ST \\
Square feet & STU \\
Square meters & SQ. FT \\
Square miles & SQ. M \\
Tons & SQ. MI \\
Troy ounces & TONS (specify long or \\
&
\end{tabular}

LIST J

DRAINAGE AREA CODES OF THE U.S.

02 Middle Atlantic region

03 South Atlantic Gulf region

04 Great Lakes region

05 Ohio region

06 Tennessee region

07 Upper Mississippi region

08 Lower Mississippi region

09 Souris-Red Rainy region

10 Missouri region

11 Arkansas-White Red region

12 Texas-Gulf region

13 Rio Grande region

14 Upper Colorado region

15 Lower Colorado region

16 Great Basin region

17 Columbia-North Pacific region

18 Columbia-South Pacific region

19 Alaska region

20 Hawaii region 


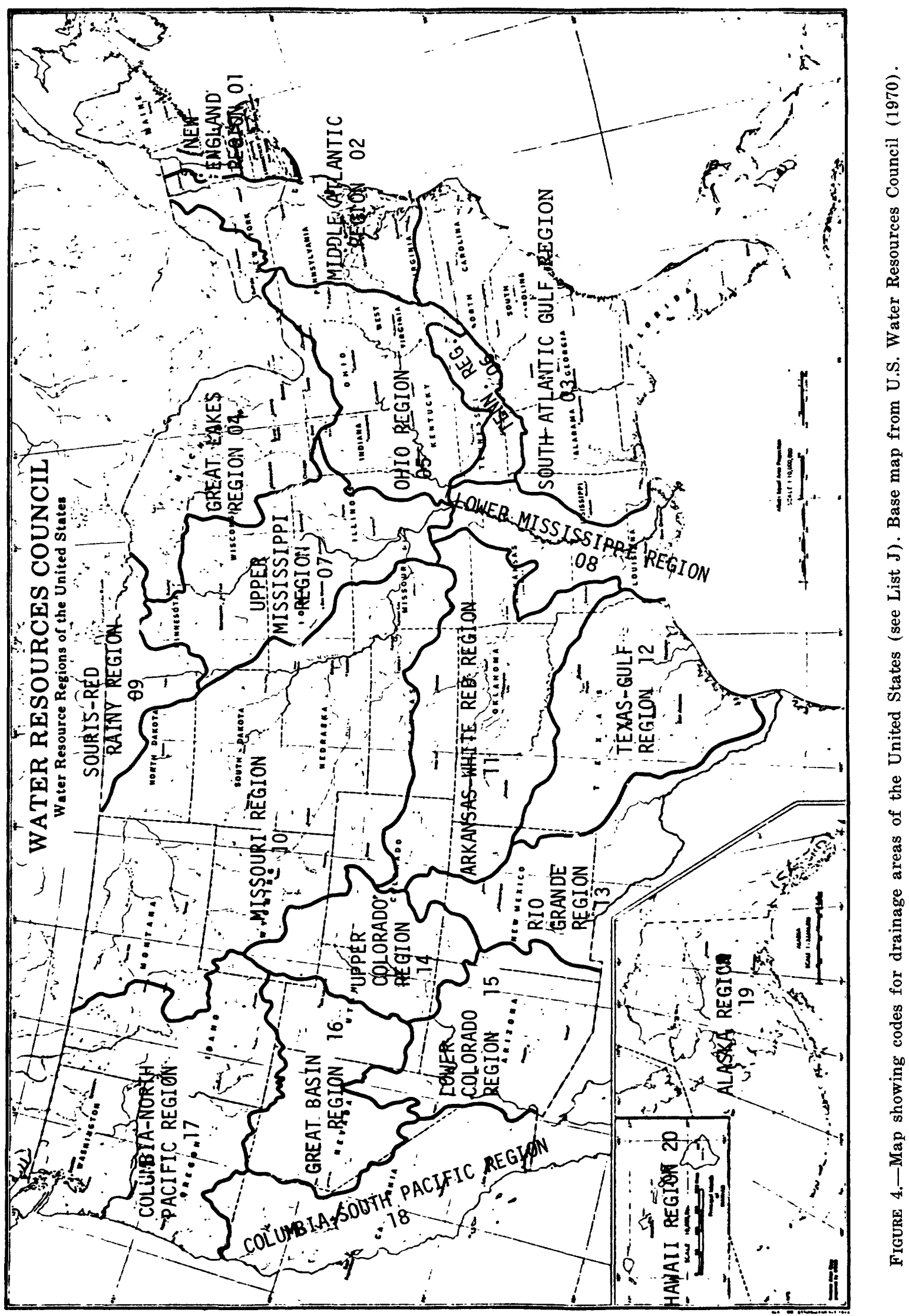


LIST K

PHYSIOGRAPHIC PROVINCES GODES OF THE U.S.

New England

Physiographic Provinec

Appalachian Highland and Triassic Lowland

Coastal Plain

Interior Highlands

Interior Lowlands

Laurentian Upland

Great Plains

Northern Rockies

Southern Rockies

Columbia Plateau

Colorado Plateau

Basin and Range

Pacific ranges

Arctic Lowland

Brooks Range

Central Highland and Basin

\section{LIST L}

\section{NATURE OF DISCOVERY}

$$
\begin{aligned}
& \text { A } \\
& \text { B } \\
& \text { C } \\
& \text { D } \\
& \text { E } \\
& \text { F }
\end{aligned}
$$$$
\text { Codr }
$$

Ill defined

Ore mineral or material in place

Ore mineral or material not in place

Geophysical anomaly

Geochemical anomaly

Other (clarify in the comments field L110 if desired)

\section{LIST M}

\section{TYPE OF WORK DONE}

$$
\text { Code }
$$

COMPILE

DIREXPL

GEOCHEM

GEOLMAP

GEOPHYS

RECON

OTHER

\section{Compilation}

Direct exploration (drilling, trenching, mining, pit and so on)

Geochemical work

Geological mapping

Geophysical work

Reconnaissance

Other types of work not covered by above. Enter OTHER under "Type of work" and clarify, if desired, in the comments field L110.

\section{LIST N}

\section{FORM/SHAPE OF DEPOSIT (Examples)}

Choose one or more, as applicable, and enter under M10. This list is not exhaustive. Other descriptive entries may be formulated by reporters as needed.

Tabular/blanket

Wedge

Pod/lens

Pinch and swell

Linear

Irregular
LIST O

\section{AUTHORIZED AGE ABBREVIATIONS}

Holocene

Pleistocene

Tertiary

Pliocene

Miocene

Oligocene

Eocene

Paleocene

Cretaceous

Jurassic

Triassic

Permian

Pennsylvanian

Mississippian

Devonian

Silurian

Ordovician

Cambrian

Precambrian

Archean

Huronian

Cenozoic

Mesozoic

Paleozoic
Quaternary
QUAT

HOLO

PLEIS

TERT

PLIO

MIO

OLIGO

EO

PALEO

CRET

JUR

TRI

PERM

PENN

MISS

DEV

SIL

ORD

CAMB

PREC

$\mathrm{ARCH}$

HUR

CEN

MES

PAL

\section{LIST P}

\section{LAND CLASSIFICATION CODES}

$\begin{array}{ll}\text { Undetermined } & 00 \\ \text { Private } & 01 \\ \text { County } & 20 \\ \text { State } & 30 \\ \text { State Forest } & 31 \\ \text { State Park } & 32 \\ \text { Offshore } & 33 \\ \text { Federal } & 40 \\ \text { National Forest } & 41 \\ \text { National Recreation Area } & 42 \\ \text { National Wilderness Area } & 43 \\ \text { National Primitive Area } & 44 \\ \text { National Park } & 45 \\ \text { National Monument } & 46 \\ \text { Indian Reservation } & 47 \\ \text { Offshore } & 48 \\ \text { Bureau of Land Management } & 49 \\ \quad \text { Administered } & \end{array}$

\section{GLOSSARY}

Alpha-numeric information (alphanumeric, alphameric)-Information consisting of any combination of digits (0-9), letters (A-Z), and special characters (such as $/, \$$, or ?,)

Assumed decimal point (implied decimal point) -A decimal point the position of which is known, but which is not physically entered (punched) into a numeric field. 


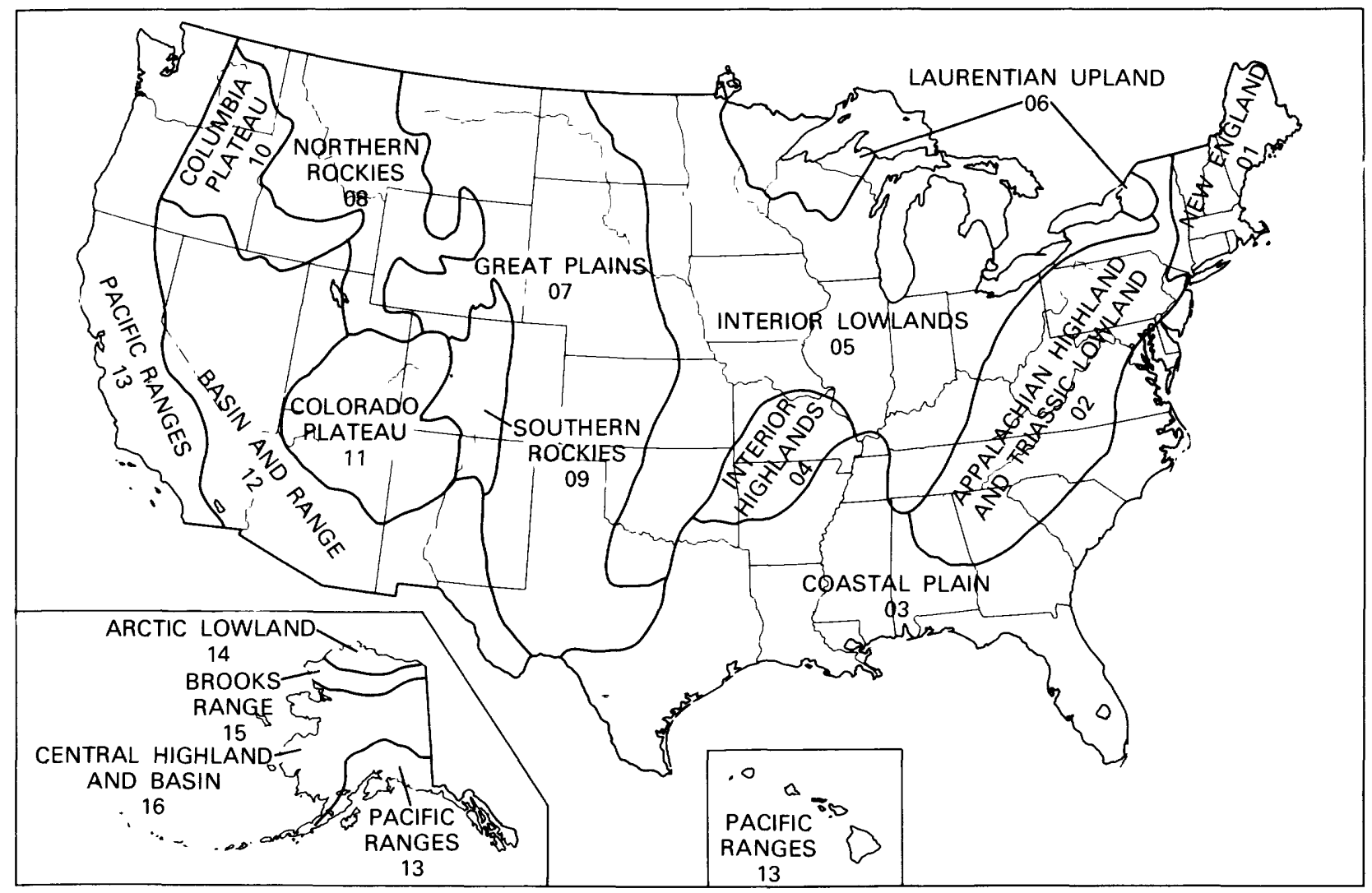

FIGURE 5.-Map showing codes for the physiographic provinces of the United States (see List K).

Batch processing-The sequential processing of records as a group (batch), one group at a time. Batch processing is in contrast to on-line processing, during which each unit of data is processed immediately at the time of presentation-as in the airline reservation system.

Baud-The speed of data transmission in bits per second.

Command procedure-A user-oriented program composed of a prearranged set of operations steps and driven by user-controlled command words, specifications, and options.

Conversational (interactive) mode-The user is communicating with the computer system in a "conversational" manner from a terminal by sending commands to the system. The system executes the commands and sends the reply back to the terminal. One type of on-line processing.

Data item (data element, information item, field) - The smallest unit of information to which reference is made; for example, "country," "State." A set of related data items constitutes a record.
Direct access-The process of finding information in storage, where the time required is independent of the location of other information in storage. A disk is a direct-access device. This is in contrast to the sequential access of tapes.

Disk (disk pack) - A storage device consisting of a circular metal plate that has magnetic material on both sides and that is mounted on a rotating shaft. Read-write heads service both sides of the disk. Ten stacked disks constitute a disk pack.

Field (data item, information item) -A specified category of data treated as a whole. The basic unit of a record.

File-A collection of related records as a unit; for example, the records file and dictionary file of CRIB. Also, in the general sense, a collection of related files; for example, the CRIB file.

File maintenance-Modification of file content; for example, insertions, deletions, transfers, and corrections. 
Fixed-fields (fixed-length fields) - An arrangement in which the fields in a record are set beforehand to a specified length.

Fixed-length records-Records of predefined length. Loosely used to mean that both record length and field length are set beforehand to specified length.

Floating decimal-A decimal point without a predetermined fixed position within a numeric field. In a six-position number field, for example, the decimal may be in any of the six positions, depending upon the size of the number.

Foreground-Interactive (conversational, online) mode of operation in which the user is communicating directly with the computer.

Foreground driver-The command procedure program forming the interface between the GIPSY program and the General Electric Mark III System.

Format-A predefined arrangement of characters, fields, print lines, and so forth. The term, "arrangement," is never used in computer work.

Interface-A program or device that translates an initial program or signal into a form compatible with the next program or device.

Job Control Language (JCL) - The language used to supply the necessary information to the computer system so that it can run your job. Includes such items as the name and address of the data file to be processed, the name of the program to be executed, what to do with the results, and so forth.

Label-As used in GIPSY, a set of one to seven alphanumeric characters used to identify a data item or field to the GIPSY program.

Literal-In the GIPSY system, a set of characters inserted into the output record of the COPY command.

Parameter statements (search variables)-A list of the data elements the computer is to search for during a retrieval.

Program-A set of instructions that tells the computer how to solve a problem.

Retrieval operation-The actions connected with the recovery of information stored in a computer storage device.
RPG (report program generator)-An IBM program language that provides a convenient programing method for producing reports, performing calculations, and manipulating data.

Software-Programs that help run the different components of a computer center and help the user to communicate with the computer.

Spanned record-A record that overflows from the end of 'one track on a disk to the beginning of the next track.

Subroutine-A program that is linked to a larger program and that performs a single task whenever the main program calls upon it to do so.

Track address-A number identifying the location where information is stored on disk.

Utility programs-Programs used to perform certain standard functions, called housekeeping functions; for example, update, transfer data from one device to another, sort programs, and so forth.

Variable fields (variable-length fields) - Fields having no predefined lengths.

Variable-length records (variable-length format) - A field or record of no predefined length.

\section{REFERENCES CITED}

Brobst, D. A., and Pratt, W. P., 1973, Introduction, in Brobst, D. A., and Pratt, W. P., eds., United States mineral resources: U.S. Geol. Survey Prof. Paper 820, p. 1-8.

Guild, P. W., 1968, Metallogenic map of North America : Comm. Geol. Map World (Internat. Geol. Cong. -Internat. Union Geol. Sci.) Bull. 8, p. 77-90.

McKelvey, V. E., 1972, Mineral resource estimates and public policy: Am. Scientist, v. 60 , no. 1 , p. 32-40 (reprinted in Brobst and Pratt, 1973, p. 9-19).

U.S. Bureau of Mines and U.S. Geological Survey, 1976, Principles of the mineral classification system of the U.S. Bureau of Mines and U.S. Geological Survey: U.S. Geol. Survey Bull. 1450-A, 5 p.

U.S. Geological Survey, 1975, Mineral resource perspectives 1975: U.S. Geol. Survey Prof. Paper 940, $24 \mathrm{p}$.

U.S. Water Resources Council, 1970, Water resource regions of the United States, Appendix 1 of Water resources regions and subregions for the National assessment of water and related land resources: Washington, D. C., map, scale 1:10,000,000. 